\title{
The Ordovician acritarch genus Coryphidium
}

\author{
Thomas Servais ${ }^{1}$, Jun $\mathbf{L i}^{2}$, Stewart G. Molyneux ${ }^{3}$, Marco Vecoli ${ }^{1}$ \\ ${ }^{1}$ Laboratoire de Paléontologie et Paléogéographie du Paléozö̈que, UMR 8014 et FR 1818 du \\ CNRS, Université des Sciences et Technologies de Lille, F-59655 Villeneuve d'Ascq Cedex, \\ France \\ ${ }^{2}$ Nanjing Institute of Geology and Palaeontology, Chinese Academy of Sciences, East Bejing \\ Road, 210008 Nanjing, China \\ ${ }^{3}$ British Geological Survey, Keyworth, Nottingham, NG12 5GG, UK \\ email : thomas.servais@univ-lille1.fr, junli@nigpas.ac.cn,sgm@bgs.ac.uk, \\ marco.vecoli@univ-lille1.fr
}

\begin{abstract}
The acritarch genus Coryphidium Vavrdová 1972 is one of the most frequently recorded acritarch taxa in the Ordovician. The original diagnoses, stratigraphical ranges and geographical distribution of all Coryphidium species are critically evaluated in a review of published literature supplemented by studies of material from the British Isles, Belgium, the Czech Republic, Germany, Spain, Morocco, Algeria, Tunisia, Lybia and China, including sections from type areas. The taxonomic concept of the genus is here rationalized: the genus Coryphidium is emended and the informal category of coryphid acritarchs is introduced to include all morphotypes with the characteristic vesicle shape of the two genera Coryphidium and Vavrdovella Loeblich and Tappan 1976. Nine of the previously described species can be attributed to the genus, and two other species possibly belong to it. The attribution to Corphydium of the species C. sichuanense Wang and Chen 1987 is rejected here. Intraspecific variability is very important and the attribution of Coryphidium specimens at the specific level is sometimes difficult. The genus is found in all palaeoenvironments from nearshore to offshore settings and apparently does not occupy specific palaeoecological niches. Coryphidium is very useful biostratigraphically and palaeobiogeographically. The review indicates that the genus first appears in the uppermost Tremadocian Araneograptus murrayi graptolite Biozone and is common through the upper Lower Ordovician and the Middle Ordovician, while Upper Ordovician occurrences might be the result of reworking. Palaeogeographically, Coryphidium is an indicator of the peri-Gondwanan acritarch "palaeoprovince" during the Early/Middle Ordovician.
\end{abstract}

Keywords: acritarchs, biostratygraphy, palaeogeography, Ordovician

Résumé : Le genre d'acritarches Coryphidium Vavrdová 1972 est un des taxon d'acritarches le plus fréquemment trouvés dans l'Ordovicien. Les diagnoses originales, les extensions stratigraphiques et les distributions géographiques de toutes les espèces de Coryphidium sont critiquement évaluées sur base d'une revision de littérature et d'études de matériel des Iles Britanniques, de Belgique, d'Allemagne, de la République Tchèque, d'Espagne, du Maroc, de l'Algérie, de la Tunisie, de Lybie et de Chine, y compris de coupes géologiques des régions types. La conception du genre est revisé : le genre Coryphidium est emendé et la catégorie informelle des acritarches coryphides est introduite pour incluire tous les morphotypes avec la forme characteristique du corps central des deux genres Coryphidium et Vavrdovella Loeblich and Tappan 1976. Neuf des espèces décrites précédemment peuvent être attribuées au genre, et deux autres espèces appartiennent peut-être au genre. L'attribution au genre Coryphidium 
de l'espèce $C$. sichuanense Wang and Chen 1987 est rejetée ici. La variation intraspecifique est importante et l'attribution de spécimen de Coryphidium au niveau spécifique est parfois difficile. Le genre est trouvé dans tous les paléoenvironnements de milieux proximaux à distaux et apparemment il n'occupe pas des niches paléoécologiques particulières. Coryphidium est très utile biostratigraphiquement et paléobiogéographiquement. La révision montre que le genre apparaît pour la première fois dans la biozone à graptolites à Araneograptus murrayi du Trémacodien supérieur et qu'il est fréquent dans la partie supérieure de l'Ordovicien Inférieur et dans l'Ordovicien Moyen, tandis que la présence dans l'Ordovicien Supérieur peut être dû à du remaniement. Paléogéographiquement Coryphidium est un indicateur de la "paléoprovince" péri-Gondwanienne pendant l'Ordovicien Inférieur/Moyen.

Mots-clés : acritarche, biostratigraphie, paléogéographie, Ordovicien

\section{Introduction}

The acritarch genus Coryphidium and its type species, Coryphidium bohemicum, are important Ordovician acritarch taxa, being widely reported from numerous localities on the periphery of the Gondwanan supercontinent since their original description by Vavrdová (1972). The easily recognizable specimens of this genus are characterized by a roundedsquare central body, with an ornament of ridges, and with the processes being concentrated at the four corners of the vesicle.

The genus is biostratigraphically and palaeobiogeographically significant. Brocke et al. (1995), Molyneux and Leader (1997) and Li et al. (2003), for example, considered Coryphidium and some of its species to be very useful for regional or international biostratigraphical correlations, while Vecoli (1999) erected the informal acritarch assemblage biozone Arbusculidium filamentosum-Coryphidium bohemicum of late Arenig age, that prooved to be useful for regional correlation in the subsurface of the Algerian Sahara. Li (1989) and Servais et al. (2003) considered the genus to be one of the three taxa that define the peri-Gondwanan acritarch 'palaeoprovince'. Furhtermore, Ghavidel-Syooki (1990) and Vavrdová (1997) described a 'Coryphidium bohemicum province' and a 'Coryphidium bohemicum acritarch bioprovince', respectively.

Several of the more frequently recorded and biostratigraphically most useful Ordovician acritarch taxa from the periphery of Gondwana have been reviewed in recent years. Frankea was revised by Servais (1993), Dicrodiacrodium by Servais et al. (1997), Arkonia and Striatotheca by Servais (1997), Ampullula by Brocke (1998), Aureotesta and Marrocanium by Brocke et al. (1998) and Arbusculidium filamentosum by Fatka and Brocke (1999). So far, however, the genus Coryphidium, has not been reviewed in detail, although it is commonly used for dating sedimentary rocks or determining palaeogeographical affinities.

The aim of the present paper is to review all published data concerning this important genus, in order to rationalize its taxonomy and to understand its relationship to Vavrdovella Loeblich and Tappan 1976, a genus of similar morphology. This study also attempts to review the biostratigraphical distribution of the genus in order to underline its potential for international correlations. In addition, all occurrences of the genus are plotted on a recent palaeogeographical reconstruction in order to understand better its palaeobiogeographical distribution. 


\section{The genus in its taxonomical context}

\subsection{The acritarch subgroup Coryphomorphitae}

Vavrdová (1972) described the genus Coryphidium and its type species C. bohemicum, from the Klabava Shales of 'Arenig age' in Bohemia. The original diagnoses and descriptions of both the genus and its type species are short and clear, although Vavrdová's (1972) diagnosis of $C$. bohemicum, based on thirty specimens is also relatively wide and allows the attribution of a great number of morphotypes to the species. Unfortunately, the exact location of the outcrop and of the type level was not indicated. The age indication ('Arenig') also remained vague and the precise biostratigraphy of the type level is still not precisely known to the present day. According to Martin (1982), the acritarchs described by Vavrdová (1965, 1966, 1973, 1976) from the locality 'U Starého hradu', south east of Klabava near Rokycany, including the type material fo Coryphidium bohemicum, are from the Tetragraptus cf. pseudobigsbyi graptolite Biozone of Kraft (1977). Martin cites as a 'pers.comm.' from Vavrdová as the authority for this. The the Tetragraptus cf. pseudobigsbyi graptolite Biozone replaced the Tetragraptus reclinatus abbreviatus Biozone, which has been correlated with the British Isograptus gibberulus Biozone (Cooper and Fortey, 1982, fig. 2).

The original diagnosis (see Systematic Palaeontology section) highlights the characteristic features of the genus by a polyhedral central body with rounded angles, the vesicle wall with an ornament of fine ribs, and the processes concentrated at the corners of the vesicle. The original generic diagnosis also states that the processes are conical, proximally open and distally heteromorphic. For C. bohemicum, Vavrdová (1972) added some precision regarding the distance between ribs (spaced about $2 \mu \mathrm{m}$ ) and the number of processes (40-60), but there is no significant difference between the original diagnoses of the genus and the type species.

One year later, Vavrdová (1973) described another new acritarch genus to which she gave the name Tetradineum not realising that the name had already been used for an extant dinoflagellate genus (Klebs 1912). Vavrdová (1976) subsequently changed the name of her gew genus to Tetraniveum, but in the meantime Loeblich and Tappan (1976) had introduced the name Vavrdovella as a replacement for Tetradineum Vavrdová 1973 (it was Alfred R. Loeblich Jr. who alerted Milada Vavrdová to the fact that Tetradineum Vavrdová 1973 was a junior homonym of the extant dinoflagellate genus). According to Fensome et al. (1990), Vavrdovella Loeblich and Tappan 1976 is the senior synonym of Tetraniveum Vavrdová 1976.

The diagnosis of the new genus 'Tetradineum' sensu Vavrdová 1973 (now Vavrdovella) was rather short: "vesicle differentiated into central body of variable outline and conical processes which are restricted to four or more areas symmetrically arranged. Processes are essentially simple, homomorph, distally pointed. Vesicle wall laevigate to microgranulate". This genus remains monospecific, its type species being $V$. areniga (Vavrdová 1973) Loeblich and Tappan 1976. According to its original diagnosis, the genus has the same central body shape as Coryphidium, but does not display the fine ribs on the vesicle wall that are characteristic of the latter genus. Furthermore, the processes of Vavrdovella are always simple, while those of Coryphidium are defined as heteromorphic and with complex branching.

Following the common use of acritarch subgroups in the 1960s (e.g. Downie et al., 1963), Vavrdová (1973) created a new subgroup, the 'Coryphomorphitae incertae sedis' (sic), with the following diagnosis: "Acritarchs having spherical to polyhedral vesicles, processes or other sculpture elements concentrated on several (more than two) areas adjoining corners of the central body. Other parts of vesicle laevigate or with different sculpture (granulate, 
echinate, striate). Processes are numerous, homomorph or heteromorph" (Vavrdová, 1973, p. 285-287). Vavrdová (1973) created this new subgroup to include the two genera Coryphidium and Tetradineum (now Vavrdovella).

\subsection{Coryphidium and Vavrdovella : a single taxonomic entity?}

The use of acritarch subgroups was abandoned by most acritarch workers in the 1970s, when an alphabetical arrangement of genera and species, first suggested by Loeblich (1970), was generally adopted instead. It is thus not surprising that the subgroup Coryphomorphitae has not been commonly used following its introduction. However, as defined by Vavrdová (1973), this subgroup can be regarded as a distinct morphological entity, clearly distinguishable by the characteristic, pillow-shaped vesicles of its constituant genera and the tendency for the processes to be concentrated at the corners.

Although Vavrdová $(1972,1973)$ indicated the possibility of polyhedral vesicles, most specimens attributed to the two genera by Vavrdová and other authors have quadrangular, pillow-shaped vesicles with rounded corners and concave, straight or convex sides. Although the distinction between Vavrdová's two genera is straightforward according to their original diagnoses, the classification scheme is not without problems. Large populations usually display a range of morphological variability and it is possible to observe specimens that are intermediates between Coryphidium and Vavrdovella, or to put it another way, specimens that do not correspond to either Coryphidium or Vavrdovella as originally diagnosed. For example, specimens with heteromorphic processes but without ridges on the central body do not correspond with the original diagnosis of Coryphidium because of the absence of ridges, but neither do they correspond with the original diagnosis of Vavrdovella because the processes are not simple and sharp-pointed. Similarly, specimens with ridges on the central body, but with simple, distally pointed processes cannot be attributed to either Coryphidium or Vavrdovella as originally defined, although such specimens clearly belong to the subgroup Coryphomorphitae. Thus, whereas the Coryphomorphitae as a super-generic category is fairly well constrained and understood, and while some species of the constituent genera are similarly well defined, it is nevertheless sometimes difficult to make an attribution at the generic level. It is therefore useful to propose here the informal term of 'coryphids' or 'coryphid acritarchs' to designate morphotypes with the characteristic vesicle shape of the Coryphomorphitae sensu Vavrdová (1973).

\subsection{Historical review of the description of "coryphid" acritarchs}

In this section, the history and the evolution of the taxonomic concepts of the 'coryphid' acritarchs are briefly summarized in order to clarify the different classification models and to explain the current problematic taxonomic situation.

The first formal description of a specimen that can clearly be attributed to the coryphids was included in Burmann's (1970) investigation of the 'late Llanvirn' $D$. murchisoni graptolite Biozone (now Darriwilian) of Rügen, Baltic Sea, Germany. Burmann (1970, p. 309; pl. 7, fig. 7) described a new species with the typical coryphid body outlines as as 'Baltisphaeridium obtusatum sp.n.' It is not sure if she observed more than one specimen. This species cannot be referred to Coryphidium because the characteristic ribs of Coryphidium are not cited in its diagnosis nor figured on the drawing, but neither can it be referred to Vavrdovella because the processes are not simple and pointed distally. However, 
from a revision of material from this locality (Servais 1994, this study), it is clear that this morphotype can be attributed to the coryphids.

Martin et al. (1970, pl. 1, fig. 3) figured a specimen as 'indéterminé forme A' from the 'Caradoc' of Ombret, in the Belgian Condroz Inlier. This specimen is also clearly a coryphid acritarch, and possibly reworked. The age of these sediments has now been reconsidered and the formation can be attributed to the early-middle Caradoc (Verniers et al., 2003 ; Owens and Servais, in press, fig. 2).

On the basis of eight specimens, which were probably also reworked, Martin (1974) described the genus Octogonium from the lower Llandovery of the Deerlijk Formation (Brabant Massif, Belgium). The diagnosis of the genus and of its type species $O$. vanguestainii includes the presence of fine ribs ("fines rides subparallèles aux côtés ... ") as well as furcate distal process terminations, which clearly indicate that Octogonium is a junior synonym of Coryphidium. It is not clear, however, if the species $O$. vanguestainii is a junior synonym of $C$. bohemicum, as indicated in Martin's (1974, p. 63) 'Addendum', because $C$. bohemicum is described as having heteromorphic processes, whereas $O$. vanguestainii is not. In a subsequent paper, Martin $(1977$, p. 23$)$ also placed $O$. vanguestainii in synonymy with $C$. bohemicum. Meanwhile, Rauscher (1974a, 1974b) had identified the species C. bohemicum from in the Ordovician of France.

The formal description of a second species of Coryphidium by Cramer et al. (1974) intoduced additional taxonomic problems. Cramer et al. (1974) reported C. bohemicum and the new species Coryphidium elegans from the 'Upper Arenigian to Lower Llanvirnian' of the Tadla Basin, Morocco. Cramer et al. (1974) provided a long but imprecise description of $C$. elegans. The location of the material was precisely indicated (borehole BJ-109, depth $360 \mathrm{~m}$ ), but Cramer et al. (1974) gave no indications of the number of observed specimens.

Coryphidium elegans was described as having "solid, slender" processes that "vary from flexible spines to hairs ; (that) occasionally ... may show some kind of tiny knob at the extreme distal termination". The holotype (Cramer et al. 1974, pl. 27, fig. 16) and the paratypes (partly republished in Cramer and Díez 1976) display essentially homomorphic, simple processes that are not furcate. Coryphidium elegans is therefore clearly distinguished from $C$. bohemicum, but at the same time it exemplifies the problem of generic definition that arose with the description of Vavrdovella (i.e. Tetradinium Vavrdová 1973) as a separate entity. Thus, although Coryphidium elegans is a typical coryphid acritarch, it does not fit the original diagnosis of Coryphidium, as it does not have heteromorphic, furcate processes but neither does it fit the diagnosis of Vavrdovella, because of its sculpture of ribs parallel to the vesicle sides. In fact, $C$. elegans could be considered as a transient between Coryphidium and Vavrdovella with ribs of the first and the processes of the second.

The taxonomy became more confused with the publication by Cramer and Díez (1976) of a further seven new species of Coryphidium, also from borehole BJ-109. All the holotypes of the new species were described from one sample (depth $510 \mathrm{~m}$ ). Cramer and Díez (1976) indicated this level and the material of Cramer et al. (1974) to be of 'Late Arenig' age, an interpretation that was confirmed subsequently by chitinozoans ( Soufiane and Achab, 1993).

Cramer and Díez (1976) provided a first bibliographical listing for C. bohemicum, from which Martin's (1974) publication was omitted. However, the specimens of Martin et al. (1970) and ?Baltiphaeridium obtusatum Burmann were placed in synonomy with $C$. bohemicum, which would make that Burmann's (1970) taxon the senior synonym.

The description of the seven new species of Coryphidium and comparison with the two previously described species is problematical. In their fig. 2, Cramer and Díez (1976) illustrated diagrammatically nine Coryphidium species described from the Arenic of Morocco: C. bohemicum Vavrdová 1972, C. elegans Cramer et al. 1974, and the new species C. almohadillum, C. australe, C. barakum, C. miladae, C. minutum, C. ramiferum, and $C$. 
tadlanum (some of the adjectival specific epithets are corrected here, according to the recommendations of the International Code of Botanical Nomenclature, I.C.B.N., article 60 ; see Systematic Palaeontology section).

The diagnoses of Cramer and Díez's (1976) seven new species of Coryphidium stated that all had a similar morphology to Coryphidium elegans, but that they could be distinguished from that species and from each other by the presence or absence of ridges and by the nature of the processes. Thus, Coryphidium almohadillum and C. barakum correspond to the original diagnosis of Coryphidium in so far as they have ridges on the vesicle, but could be distinguished from $C$. bohemicum and $C$. elegans by their shorter processes. Coryphidium ramiferum alo has the morphological features of Coryphidium, with the ribs on the vesicle and processes that branch into a crown, and might be distinguished from $C$. bohemicum, $C$. elggans, $C$. almohadillum and $C$. barakum by the morphology and distribution of its processes. However, neither Coryphidium australe nor $C$. miladae agree with the original diagnosis of also Coryphidium (both species have no ridges on the vesicle wall), nor with that of Vavrdovella (both species have no processes with complex distal terminations). The two remaining species, Coryphidium minutum and C. tadlanum, also lack ridges and therefore these too do no correspond to the original diagnosis of Coryphidium.

All the species introduced by Cramer et al. (1974) and Cramer and Díez (1976) display typical coryphid morphology, but problems arise because these authors did not indicate how many specimens each of their species was based upon, nord id they discuss the range of variability within eachs species. The lack of any evidence for discussion of variability within Coryphidium species described by Cramer and Díez (1976) is a major impediment to understanding their relationship to each other and to Coryphidium bohemicum and C. elegans. Some of Cramer and Díez's (1976) species are very similar to others. For example, it is virtually impossible to distinguish Coryphidium almohadillum from C. barakum on the basis of their diagnoses or illustrations (both species are characterized by very short processes, with overlapping dimensions and morphologies), and Coryphidium australe closely resembles $C$. miladae (both lack ridges on the vesicle wall and have similar processes). It is quite possible that each pair represents only a single species, and indeed possible the whole population of coryphid acritarchs described by Cramer et al. (1974) and Cramer and Díez (1976) from Morocco has been over-split because these authors did not take sufficient account of intraspecific variability when describing their material.

More recently, a further three species have been described. Coryphidium sichuanense Wang and Chen 1987 from the lower Cambrian of southern China has none of the characteristics of coryphid acritarchs and its attribution to Coryphidium is rejected here. The specimens of Wang and Chen (1987) might be better attributed to Micrhystridium sp.

Ghavidel-Syooki (1990) recorded Coryphidium bohemicum and C. elegans from the Ordovician of Iran, but also erected the new species 'Coryphidium persica' (persica is here corrected to persianum, on teh grounds that the specific epithet is based on a geographical name, Persia, I.C.B.N., article 60). Ghavidel-Syooki (1990) made no mention of ridges on the vesicle and it is not possible to observe such structures on the illustrated specimens. The new species was characterized by a "translucent membrane connected to the body by a set of filose processe elements". The presence of membranes within the genus Coryphidium has not been recorded previously, and therefore the species is here only questionably attributed to the genus. Moreover, the species remains invalid, because Ghavidel-Syooki (1990) did not indicate a holotype among the four illustrated specimens (I.C.B.N., article 37).

The third species, Coryphidium longispinosum, with relatively long processes, was described by Garo (1991) from the Lower Ordovician of Yunnan Province. There is no indication in the original diagnosis whether the speies has an ornament of (fine) ribs, and the photograph of the holotype is too poor to resolve this question. Hence, it is not clear if the 
holotype of $C$. longispinosum corresponds with the diagnoses of Coryphidium or Vavrdovella. In this paper, the species longispinosum is therefore only questionable attributed to the genus Coryphidium.

Finally, some authors have described Coryphidium morphotypes in open nomenclature. Molyneux and Leader (1997) for example, described three morphotypes that were considered useful for regional biostratigraphy of British sections.

\section{Material and methods}

The material analysed in this study is from Belgium, the Czech Republic, Germany, England and Wales, Spain, Morocco, Algeria, Tunisia, Lybia and China. All localities were investigated by the authors in previous studies, to which the reader is referred for more detailed geological descriptions.

The Belgian material is from Llanvirnian (Darriwilian) levels of the Rigenée Formation in the Brabant Massif, previously investigated by Martin (1969) and Servais (1991) and more recently dated using chitinozoans by Samuelsson and Verniers (2000), and from the early Llanvirnian (middle Darriwilian) Huy formation of D. artus graptolite Biozone age in the Condroz Inlier, previously investigated by Servais and Maletz (1992). For the review of the stratigraphy of these localities, seeVerniers et al. (2001).

German localities investigated here are in the Ebbe Anticline of the Rhenish Massif, western Germany, and boreholes on the island of Rügen, Baltic Sea. Material from the Ebbe Anticline was previously studied by Maletz and Servais (1993), and acritarchs from the Ordovician sequence of Rügen have been described in several papers, incuding those of Burmann (1970), Servais (1994) and Servais and Molyneux (1997). For a detailed review of the stratigraphy of the Ebbe anticline and the Rügen boreholes, see Samuelsson et al. (2002) and Servais et al. (2001), respectively.

Two samples from the Czech Republic were provided by M. Vavrdová to the senior author in 1990, including part of the sample from which the genus Coryphidium was originally described (a sample from the locality ' $U$ Starého hradu' at Klabava near Rokycany). The second sample comes from the 'Llanvirnian' of 'Krusna Horá' near Beroun, mine 'Gabriela'-K3. The first sample is from the upper part of the Klabava Formation, and the second sample from the lower part of the Sárka Formation, but the precise positions and ages of the two samples are unknown. For a recent review of the regional stratigraphy of the area, see Kraft and Kraft (2003).

The Moroccan samples investigated here come from the borehole Boujad-109 of the Tadla Basin. Two samples from depths $360 \mathrm{~m}$ and $511 \mathrm{~m}$ were made available to $\mathrm{M}$. Vanguestaine (Liège University, Belgium) in 1982. Soufiane and Achab (1993) indicated a late Arenig age for depths between 481 and $512 \mathrm{~m}$ (see biostratigraphy chapter).

The Spanish material reinvestigated for this study was previsously analysed by Mette (1989) and restudied by Servais and Mette (2000).

British specimens of Coryphidium are from the Lower-Middle Ordovician (Tremadocian-Darriwilian) succession of the English Lake District (Rushton and Molyneux, 1989 ; Copper and Molyneux, 1990 ; Cooper et al., 2004), from the correlative succession of the Isle of Man (Molyneux 1999; Chadwick et al. 200x), and from south Wales (Molyneux, 1987). The Lake District material formed the basis of the analysis by Molyneux and Leader (1997). Additional specimens have been recorded from north Wales in unpublished thesis work (Booth, 1979) and from the Upper Ordovician (Caradoc) of the Welsh Borderland, where they were considered to be reworked (Turner, 1982). 
Well preserved palynological assemblages containing relatively abundant specimenss of Coryphidium from the subsurface of the Algerian Sahara (borehole NL-2) and of the Ghadamis Basis of southernmost Tunisia (boreholes ST-1, TT-1) and northwestern Libya (borehole A1-70) were previously analysed by Vecoli (1999 and unpublished data) and Vecoli et al. (2004), and are reconsidered for the present study. Age attributions were based on palynological grounds and indirect correlations (e.g., late Arenig age of the Algerian Sahara material) as well as on the basis of co-occurring chitinozon index-species (ornensis chitinozoan Biozone, late Arenig, in the A1-70 borehole of the Ghadamis Basin ; Vecoli and Quintavalle, unpublished).

The Chinese material is from different sections analysed in papers by $\mathrm{Li}$ and coworkers. For a complete list of the localities investigated by Li, see Li et al. (2002).

\section{Systematic palaeontology}

\subsection{Original and emended diagnosis of the genus Coryphidium}

As indicated above, some species attributed to Coryphidium do not comply with the original diagnosis of Vavrdová (1972). Therefore, the diagnosis is here emended to include all coryphid acritarchs that display the sculptural ridges on the vesicle wall, but also a wider range of process morphologies, including both branched and simple processes. The emended diagnosis allows the inclusion of all morphotypes with simple, distally unbranched processes, namely the specimens attributed to Coryphidium elegans.

\section{Group Acritarcha Incertae Sedis Evitt 1963}

Genus Coryphidium Vavrdová 1972 emend. nov. Servais, Li, Molyneux and Vecoli

\section{Type species. Coryphidium bohemicum Vavrdová 1972}

Original diagnosis (Vavrdová 1972, p. 84): "Acritarchs with polyhedral main body, angles rounded. Wall thin, single-layered, in places sculptured with very fine ribs. Numerous processes, equal in length, symmetrically distributed at angles of polyhedron and adjoining edges. Processes are conical, proximally opened, distally heteromorphic (truncate, bifurcate, plurifurcate)".

Emended diagnosis: Quadrangular, pillow-shaped vesicle with rounded corners. Sides of the vesicle concave, convex or straight. Sculptural ridges mostly more or less parallel to the sides, covering almost the entire vesicle wall ; some ridges may extend diagonally across the vesicle from corner to corner. Numerous processes, which in some cases tend to be concentrated at the corners of the vesicle but in others are distributed more widely and at random across the surface of the vesicle. The processes are of various length and morphology: being simple and sharp-tipped, or distally branched or truncated.

Comparison: Coryphidium is readily distinguished from all other acritarch genera. Vavrdovella has a similar vesicle outline, but it never has the sculptural ridges parallel to the vesicle sides, that are characteristic of Coryphidium. In addition, Vavrdovella has so far only been described with simple, distally tapering processes. Although it is a characteristic feature of the type species and certain other Coryphidium morphotypes, the concentration of processes at the corners of the vesicle is not always marked, and other species and 
morphotypes of Coryphidium have more random and widespread process distributions across the vesicle. It is also possible to find intermediates between Coryphidium with processes concentrated at the four corners of the vesicle and Acanthodiacrodium with a typical diacromorph process distribution (processes concentrated at two opposing poles of the vesicle), for example Acanthodiacrodium? dilatum Molyneux in Molyneux and Rushton 1988 and Acanthodiacrodium? sp. 1 in Servais and Molyneux (1997). Such specimens are possible transients between diacromorph acritarchs, dominant in assemblages throughout the Tremadocian, and coryphid acritarchs, which first appear in the late Tremadocian. Such transients have been reported in several studies of late Tremadocian acritarchs, including Martin (1996), Brocke (1997), Servais and Molyneux (1997), Connery and Higgs (1999), Servais and Mette (2000), Vanguestaine and Servais (2002) and Breuer and Vanguestaine (2004).

\subsection{Bibliographical review of Coryphidium species}

Based on previous attributions to the genus Coryphidium, and following the emended diagnosis, nine species are currently considered to belong to the genus. These nine species are, in alphabetical order :

C. almohadillum Cramer and Díez 1976

C. australe Cramer and Díez 1976

C. barakum Cramer and Díez 1976

C. bohemicum Vavrdová, 1972

C. elegans Cramer et al. 1974

C. miladae Cramer and Díez 1976

C. minutum Cramer and Díez 1976

C. ramiferum Cramer and Díez 1976

C. tadlanum Cramer and Díez 1976

The two questionable species (one of which is technically invalid as a holotype has not been selected) are:

\section{C. ? longispinosum Gao 1991 \\ C. ? persianum Ghavidel-Syooki 1990 (invalid species)}

The original diagnoses of all 11 species are included here. The taxonomic position is discussed and all species are briefly described. The stratigraphical and palaeogeographical distribution of all species is summarized, based on a review of all literature citations. Bibliographical lists are included for all 11 species. It is important to understand that these bibliographical lists are not to be considered as synonomy lists, however.

The following abbreviations are used in the bibliographical lists:

-: determination correct, according with the original description

?: determination questionable non: determination not accepted

*: no specimens illustrated (determination impossible to control) pp: pro parte 
Coryphidium almohadillum Cramer and Díez 1976

Coryphidium almohadilla n.sp. - Cramer and Díez 1976, p. 204, text-fig. 2 : 3, pl. 23 : figs. 8, 11.

Coryphidium almohadilla Cramer and Díez 1976. - Eisenack et al. 1979, p. 77.

?Coryphidium almohadilla Cram. and Díez. - Kalvacheva 1979, p. 1399, pl. 1 : fig. 12.

Coryphidium almohadilla Cramer and Díez 1976. - Downie 1984, text-fig. 4 : 34.

* Coryphidium cf. almohadilla Cramer and Díez 1976. - Mette 1989, p. 7.

*Coryphidium almohadillum Cramer and Díez 1976. - Fensome et al. 1990, p. 155.

*Coryphidium almohadillum. - Fensome et al. 1991, p. 3.

Coryphidium sp. cf. C. almohadillum Cramer and Díez 1976. - Connery and Higgs 1999, p. 136, 150 , pl.2 : fig. 8.

non Coryphidium almobadilla Cramer and Díez 1976 (misspelling). - Xu 1999, p. 65, 75, pl. 1 : fig. 14.

*Coryphidium cf. almohadillum Cramer and Díez 1976. - Maziane et al. 2000, p. 62, 65, 6768.

Coryphidium cf. almohadillum Cramer and Díez 1977 (sic). - Todd et al. 2000, p. 830.

Holotype : Cramer and Díez 1976, p. 204, pl. 23 : fig. 8.

Type locality and type level : Boujad, Tadla Basin, Morocco, borehole BJ-109, depth $510 \mathrm{~m}$.

Original diagnosis (Cramer and Díez 1976): "Species of Coryphidium of a similar morphology to that of $C$. elegans, but distinguished from it in that $C$. almohadilla has numerous fine rugulae. These are arranged in a regular pattern and parallel to the sides of the body. Furthermore, it displays a dense cover of small mainly aculeate elements which in their majority are located on the crests of the rugulae. A few of the elements may be capitate, but most are sharp-tipped".

Nomenclatural note : Following Fensome et al. (1990), Coryphidium almohadilla is corrected here to C. almohadillum (I.C.B.N., Article 60).

Remarks : This is clearly a species of Coryphidium, its main diagnostic characteristic being very short processes. Cramer and Díez (1976) indicated that the process length could be up to $2 \mu \mathrm{m}$, but was generally $1 \mu \mathrm{m}$ or less. The species is very close to $C$. barakum, which also has very short processes (elements up to $3 \mu \mathrm{m}$ according to Cramer and Díez, 1976 ; with pinnae smaller than $0.5 \mu \mathrm{m}$ on branched processes).

Biostratigraphical and palaeobiogeographical distribution: There have been few records of C. almohadillum since its original description. The determination of Kalvacheva (1979) at the specific level is questionable. Specimens with very short processes occur close to the Tremadoc-Arenig boundary in Ireland (Connery and Higgs 1999).

\section{Coryphidium australe Cramer and Díez 1976}

Coryphidium australe n. sp. - Cramer and Díez 1976, p. 205, text-fig. 2 : 5; pl. 23 : figs. 5-6.

Coryphidium australe Cramer and Díez 1976. - Eisenack et al. 1979, p. 79.

*Coryphidium australe Cramer et Díez. - Smith 1981, p. 143. 
Coryphidium australe Cramer and Díez 1976. - Turner 1982, p. 122-123, 125, pl. 17 : fig. 4. Coryphidium australe Cramer and Díez 1976. - Albani et al. 1985a, p. 50-51, 58, 60; pl. 6, fig. 10.

*Coryphidium australe. - Fang 1986, p. 135.

?Coryphidium australe Cramer and Díez 1976. - Albani 1989, p. 5, 7, 13, pl. 1 : figs. 18-19.

Coryphidium australe. - Li 1990, p. 142, 147, 157, pl. 3 : fig. 12, pl. 5 : fig. 5.

* Coryphidium aff. australe Cramer et Díez. - Vavrdová 1990b, p. 242.

*Coryphidium australe Cramer and Díez 1976. - Fensome et al. 1990, p. 155.

* Coryphidium australe. - Fensome et al. 1990, p. 9.

*Coryphidium australe Cramer et Díez 1976. - Servais 1991, p. 240.

Coryphidium australe. - Reitz 1994, p. 664, pl. 1 : fig. 21.

Coryphidium australe Cramer et Díez 1976. - Li and Yuan 1998, p. 274, 277, 285, pl. 4 : figs. 9, 10, 14.

*Coryphidium australe Cramer et Díez 1976. - Rubinstein et al. 1999, p. 271-272, 274.

Coryphidium cf. australe Cramer and Díez 1976. - Brocke et al. 2000, p. 37, pl. 2 : fig. 1.

*Coryphidium australe Cramer et Díez 1976. - Rubinstein and Toro, 2001, p. 426, 428, 431.

Holotype : Cramer and Díez 1976, p. 205, pl. 23 : fig. 20.

Type locality and type level : Boujad, Tadla Basin, Morocco, borehole BJ-109, depth $510 \mathrm{~m}$.

Original diagnosis (Cramer and Díez 1976): "Species of Coryphidium of a similar morphology to that of $C$. elegans, but distinguished from it in that $C$. australe has no rugulae, and has no filose elements. It shows instead a dense cover of plump, short processes. These processes are cylindrical to columnar and may have a few denticulate branches at about half height. They may be sharp-tipped, flat-capitate, or expanded by distal dichotomy".

Remarks : This species was described as having no ridges on the vesicle, and therefore it does not correspond with the original diagnosis of Coryphidium. Several authors have described and/or illustrated this morphotype with its characteristic plump, short processes, but without clearly visible ridges. It is possible that poorly preserved specimens of $C$. bohemicum, on which the fine details of the distal process ornamentation is no longer visible, have been described as C. australe.

Biostratigraphical and palaeobiogeographical distribution: As with $C$. almohadillum, there have been few records of $C$. australe since its original description. It occurs in several European and Chinese localities. Most records are of poorly preserved material.

\section{Coryphidium barakum Cramer and Díez 1976}

Coryphidium baraka n. sp. - Cramer and Díez 1976, p. 205, text-fig. 2 : 5, pl. 23 : figs. 5-6. Coryphidium baraka Cramer and Díez 1976. - Eisenack et al. 1979, p. 81.

?Coryphidium baraka Cramer et Díez 1976. - Marhoumi et al. 1982, p. 139, pl. 1 : figs. 2122.

*Coryphidium cf. baraka Cramer and Díez 1976. - Mette 1989, p. 7.

?Coryphidium baraka Cramer et Díez 1976. - Albani 1989, p. 5, 13, pl. 1 : figs. 20, 23, 25.

* Coryphidium barakum Cramer and Díez 1976. - Fensome et al. 1990, p. 155.

* Coryphidium barakum. - Fensome et al. 1990, p. 9.

?Coryphidium baraka Cramer and Díez 1976. - Reitz and Höll 1991, p. 331, pl. 1, fig. 7. 
*Coryphidium cf. baraka Cramer and Díez 1976. - Reitz and Höll 1992, p. 199.

*Coryphidium barakum Cramer and Díez 1976. -Quintavalle et al. 2000, p. 6, 9.

Holotype : Cramer and Díez 1976, p. 204, pl. 23 : fig. 8.

Type locality and type level : Boujad, Tadla Basin, Morocco, borehole BJ-109, $510 \mathrm{~m}$.

Original diagnosis (Cramer and Díez, 1976): "Species of Coryphidium of a similar morphology to that of $C$. elegans, but distinguished from it in that $C$. baraka has a dense cover of rugulae which are arranged in a regular pattern parallel to the sides of the body. The filose elements are numerous, small and short; they vary from aculeate to flagellate, or capitate; some are even bi- or trifurcated distally, with very short pinnae $(<0,5 \mu) "$.

Nomenclatural note : Following Fensome et al. (1990), Coryphidium baraka is corrected here to $C$. barakum (I.C.B.N., Article 60).

Remarks: This species clearly belongs to Coryphidium. It also fits into the diagnosis of $C$. bohemicum. In the original description Cramer and Díez (1976) only compared the species with $C$. elegans, but not with the type species bohemicum. The authors differentiated the new species because of its very short processes $(<0.5 \mu \mathrm{m})$. However, this is also the main characteristic feature of $C$. almohadillum, from which $C$. barakum is very difficult to distinguish.

Biostratigraphical and palaeobiogeographical distribution: It is not clear whether the specimens of $C$. barakum recorded since the original description truly represent the species. All later citations are questionable and/or the specimens were not illustrated.

\section{Coryphidium bohemicum Vavrdová 1972}

?Baltisphaeridium cf. cristatum. - Downie and Ford 1966, p. 322, pl. 17 : fig. 7.

Indéterminé Forme A. - Martin et al. 1970, p. 346, pl. 1 : fig. 3.

?Baltisphaeridium cf. cristatum Downie (in Downie and Ford 1966). - Lister et al. 1969, p. 98.

?Baltisphaeridium obtusatum sp.n. - Burmann 1970, p. 309, pl. 7 : 7.

Acanthodiacrodium sp. - Rauscher 1971, p. 292, 296, pl. 1, fig. 7.

Coryphidium bohemicum sp. nov. - Vavrdová 1972, p. 84-85, text-fig. 4, pl. 1 : figs. 1-2.

Coryphidium bohemicum Vavrdová 1972. - Rauscher 1974a, p. 79, 162, pl. 3 : figs. 21-22, 27-28, pl. 9 : figs. 17-18.

Coryphidium bohemicum Vavrdová. - Rauscher 1974b, pl. 1 : fig. 19.

Coryphidium bohemicum Vavrdová. - Vavrdová 1974, p. 173-174, text-fig. 1 : 18.

*Coryphidium bohemicum Vavrdová 1972. - Cramer et al. 1974, p. 184.

?Octogonium vanguestainii nov. sp. - Martin 1974, p. 9, 23-24, 31, 43, 46-47, 63, text-fig. 10, pl. 4 : figs. $119,121$.

Coryphidium bohemicum Vavrdová 1972. - Eisenack et al. 1976, p. 145-146.

?Baltisphaeridium obtusatum Burmann 1970. - Eisenack et al. 1976, p. 103.

?Baltisphaeridium obtusatum n.sp. (sic); Burmann 1976, table 1: 74.

*Coryphidium bohemicum. - Vavrdová 1976, p. 62.

Coryphidium bohemicum Vavrdová 1972. - Cramer and Díez 1976, p. 203, text-fig. 2 : 1.

*Coryphidium bohemicum Vavrdová 1972. - Díez and Cramer 1977, p. 5, 30. 
*Coryphidium bohemicum Vavrdová. - Vavrdová 1977, p. 111.

*Coryphidium bohemicum Vavrd. 1972. - Fournier-Vinas and Donnot 1977, p. 125.

Coryphidium bohemicum Vavrdová, M., 1972. - Martin 1977, p. 23-24, pl. 4 : fig. 30, pl. 5 :

fig. 4.

Coryphidium bohemicum Vavrdová 1972. - Fournier-Vinas 1978, p. 266, pl. 2, figs. 32-34.

*Coryphidium bohemicum Vavrd. - Vavrdová 1978, p. 72.

Coryphidium bohemicum Vavrdová 1972. - Martin in Dean and Martin 1978, p. 7, 10-11, pl. 2 : figs. $1-2,5$, pl. 3 : fig. 25.

Coryphidium bohemicum Vavrdová 1972. - Martin and Rickards 1979, p. 191,pl. 1 : fig. 4.

Coryphidium bohemicum Vavrdová 1972. - Turner and Wadge 1979, p. 407, 411, pl. 18 : figs. 1-3.

*Coryphidium bohemicum Vavrdová 1972. - Molyneux 1979, p. 417-419.

*Coryphidium cf. bohemicum Vavrdová 1972. - Molyneux 1979, p. 416-417.

*Coryphidium bohemicum Vavrdová. - Xing 1980, p. 438.

Coryphidium bohemicum Vavrdová 1972. - Cocchio 1981, p. 74-75, 98; pl. 2 : fig. 18.

*Coryphidium cf. bohemicum Vavrdová 1972. - Cocchio 1981, p. 7.

* Coryphidium bohemicum. - Barca et al. 1981, p. 384.

Coryphidium bohemicum Vavrdová 1972. - Cocchio 1982, p. 28; pl. 1 : fig. 19.

* Coryphidium bohemicum Vavrdová 1972. - Martin 1982, p. 32-33.

*Coryphidium bohemicum. - Vavrdová 1982a, p. 148, 152.

*Coryphidium bohemicum Vavrdová. - Vavrdová 1982b, p. 338.

Coryphidium cf. bohemicum Vavrdová 1972. - Marhoumi et al. 1982, p. 139; pl. 1 : fig. 23.

*Coryphidium bohemicum Vavrdová 1972. - Turner 1982, p. 122-123, 125.

Coryphidium bohemicum Vavrdová 1972. - Downie 1984, text-fig. 4 : 23.

*Coryphidium bohemicum (Vavrd.). - Fournier-Vinas 1985, p. 809.

*Coryphidium bohemicum Vavrdová 1972. - Albani et al. 1985b, p. 12.

*Coryphidium bohemicum Vavrdová. - Vavrdová 1986, p. 356.

*Coryphidium bohemicum Vavrdová 1972. - Vanguestaine 1986, p. 74.

Coryphidium bohemicum Vavrdová 1972. - Fang 1986, p. 132, 135-136, 139-140, 146-147, 157, pl. 4 : fig. 2.

Coryphidium bohemicum Vavrdová 1972. - Li 1987, p. 616, 630, pl. 72 : figs. 5, 9.

* Coryphidium aff. bohemicum. - Trythall et al. 1987, p. 35.

pp Coryphidium bohemicum Vavrdová 1972. - Molyneux 1987, p. 324, figs. 14-18, ? 20.

Coryphidium bohemicum Vavrdová 1972. - Arriaga e Cunha and Vanguestaine 1988, p. 72, pl. 1 : fig. 9.

Coryphidium cf. bohemicum Vavrdová 1972. - Arriaga e Cunha and Vanguestaine 1988, p. 72 , pl. 1 : fig. 10.

*Coryphidium bohemicum 1972. - Vavrdová 1988, p. 8.

*Coryphidium bohemicum Vavrdová 1972. - Mette 1989, p. 7.

Coryphidium bohemicum. - Vavrdová 1989, p. 404-405, text-fig. 1 : L2.

Coryphidium bohemicum Vavrdová 1972. - Albani 1989, p. 5, 13-14, pl. 1 : figs. 21-22.

Coryphidium aff. bohemicum Vavrdová 1972. - Rushton and Molyneux 1989, p. 271-273, text-fig. 4 : C, E-G, I, L.

Coryphidium cf. bohemicum Vavrdová 1972. - Steemans 1989, p. 302, fig. 145, pl. 2 : fig. 7.

*Coryphidium bohemicum Vavrdová. - Vavrdová 1990b, p. 242-243.

*Coryphidium aff. bohemicum ? Vavrdová 1972. - Cooper and Molyneux 1990, p. 151-152.

Coryphidium bohemicum Vavrdová. - Li 1990, p. 142, 147, 157, 159, pl. 3 : fig. 10.

*Coryphidium bohemicum Vavrdová 1972. - Fensome et al. 1990, p. 155.

Coryphidium bohemicum Vavrdová 1972. - Ghavidel-Syooki 1990, pl. 4 : figs. 5-8.

*Coryphidium bohemicum. - Fensome et al. 1991, p. 9. 
?Coryphidium bohemicum Vavrdová 1972. - Reitz and Höll 1991, p. 331; pl. 1 : figs. 8-9.

* Coryphidium bohemicum Vavrdová 1972. - Herbosch et al. 1991, p. 203.

Coryphidium bohemicum Vavrdová 1972. - Servais 1991, p. 240, pl. 1 : fig. 2.

*Coryphidium bohemicum Vavrdová. - Gao 1991, p. 446-449, 455.

*Coryphidium bohenicum Vavrdová (misspelling). - Gao 1991, p. 447.

*Coryphidium cf. bohimicum Vovrdova (misspelling). - Gao 1991, p. 454.

*Coryphidium aff. bohemicum Vavrdová 1972. - Millward and Molyneux 1992, pp. 81, 83, 85.

*Coryphidium bohemicum. - Reitz and Höll 1992, p. 199.

Coryphidium bohemicum Vavrdová 1972. - Maletz and Servais 1993, p. 131, 133, 134, fig. $5: 1-2$.

Coryphidium bohemicum Vavrdová 1972. - Tongiorgi et al. 1994, p. 596-597, 599, 603, pl. 2 : fig. 2.

*Coryphidium bohemicum Vavrdová 1972. -Tongiorgi et al. 1995, p. 15-17.

Coryphidium bohemicum Vavrdová. - Li and Yuan 1995, p. 61, pl. 1 : figs. 6-8.

Coryphidium bohemicum Vavrdová 1972. - Yin 1995, p. 50-51, pl. 18 : figs. 10-11.

Coryphidium bohemicum Vavrdová. - Xu et al. 1995, p. 291, pl. 1 : fig. 2.

*Coryphidium bohemicum. - Cooper et al. 1995, p. 190-191.

*Coryphidium aff. bohemicum. - Cooper et al. 1995, p. 190.

*Coryphidium bohemicum. - Martin 1996, p. 5-6.

*Coryphidium bohemicum ?. - Molyneux 1996, p. 546-547.

*Coryphidium sp. aff. C. bohemicum. - Molyneux 1996, p. 546-548.

Coryphidium bohemicum Vavrdová 1972. - Ghavidel-Syooki 1997, p. 390, 402, pl. 3 : fig. 3.

Coryphidium bohemicum Vavrdová 1972. - Vavrdová 1997, p. 33-35, fig. 4 F, fig. 5 D.

Coryphidium bohemicum ?. - Molyneux and Leader 1997, p. 81, 83-85, 87-88, 90-93, pl. 1 : figs. 7-11.

Coryphidium sp. aff. C. bohemicum. - Molyneux and Leader 1997, p. 81, 83-85, 87-88, 9093, pl. 1 : figs. $12-15$.

*Coryphidium bohemicum. - Servais and Fatka 1997, p. 622.

*Coryphidium bohemicum Vavrdová 1972. - Tongiorgi et al. 1998, p. 186.

Coryphidium bohemicum Vavrdová 1972. - Li and Yuan 1998, p. 274, 277, pl. 4: figs. 11-13.

Coryphidium bohemicum Vavrdová 1972. - Connery and Higgs 1999, p. 136, 142, 146, 148, pl. 2, fig. 4.

Coryphidium bohemicum. - Molyneux 1999, p. 31, fig. 3b.

Coryphidium aff. bohemicum. - Molyneux 1999, p. 31, fig. 3g.

Coryphidium bohemicum Vavrdová 1972. - Vecoli 1999, p. 1, 12-13, 15, 19, 24, 37-38, 68, 80 ; pl. 5, fig. 9.

*Coryphidium bohemicum Vavrdová 1972. - Vecoli et al. 1999, 331, 334, 338-339.

Coryphidium bohemicum Vavrdová 1972. - Xu 1999, p. 65, 75, pl. 1 : fig. 9.

Coryphidium bohemicum Vavrdová 1972. - Quintavalle et al. 2000, p. 5-6, 9, pl. 1 : fig. 8.

*Coryphidium bohemicum Vavrdová 1972 sensu stricto. - Brocke et al. 2000, p. 32.

*Coryphidium bohemicum group. - Brocke et al. 2000, p. 31-32.

Coryphidium cf. bohemicum Vavrdová 1972. - Maziane et al. 2000, p. 62, 65, 67, pl. 1 : fig. 9 , pl. 2 : fig. 1.

Coryphidium bohemicum. - Todd et al. 2000, p. 829-830, 832, fig. 10d.

Coryphidium bohemicum Vavrdová 1972. - Li et al. 2002, p. 97-99, 101, pl. 1 : fig. 7.

Coryphidium cf. C. bohemicum Vavrdová 1972. - Rubinstein and Toro, p. 426-428, 431, 434, pl. 1 : fig. 4.

*Coryphidium bohemicum. - Li et al. 2003, p. 96-98.

*Coryphidium bohemicum. - Rubinstein 2003, p. 125. 
Holotype : Vavrdová 1972, p. 84, pl. 1 : figs. 1-2, text-fig. 4.

Type locality and type level: Klabava near Rokycany (Czechoslovakia), Klabava Shales.

Original diagnosis (Vavrdová 1972) : "Outline rhombic, octagonal or sub-polygonal, sides convex, straight or concave. Wall single-layered, with microrugulate to microstriate sculpture. Ribs are positive, closely spaced (about 2 microns), parallel to edges, diminishing towards angles. Numerous conical processes (usually from 40 to 60 in number) are heteromorphic, proximally opened. Distally processes are closed, truncated, bifurcate, plurifurcate (both ombrellate and roset-(sic)like), laciniate, filled at their terminations. The distribution of processes is symmetrical, with an obvious concentration to the angles".

Remarks : As indicated in the bibliographical list, Coryphidium bohemicum has been recorded from numerous localities in over 80 publications. Vavrdová's (1972) diagnosis is rather wide and allows inclusion of many morphologies. The specimens attributed to C. bohemicum and illustrated in previous publications therefore show a wide range of process morphologies. Usually, C. bohemicum was distinguished from C. elegans, the second most recorded species, on the basis of the different process shape (more complex branching for bohemicum, more simple and tapering processes for elegans), although it is difficult to draw a limit between these two extreme morphologies. Some authors strictly followed the definition of Vavrdová (1972) and used the term Coryphidium bohemicum Vavrdová 1972 sensu stricto (e.g. Brocke et al. 2000), while others accepted some morphological variation (e.g. Molyneux and Leader 1997).

Biostratigraphical and palaeobiogeographical distribution : C. bohemicum has very widely been reported from numerous localities in the Lower and Middle Ordovician of periGondwana. A detailed review of its distribution is provided in the biostratigraphy and palaeobiogeography chapters.

Coryphidium elegans Cramer et al. 1974

Coryphidium elegans n.sp. - Cramer et al. 1974, p. 182-184, 189, pl. 27 : figs. 12-19.

Coryphidium elegans Cramer, Allam, Kanes and Díez 1974. - Cramer and Díez 1976, p. 201204, pl. $23: 1-2,21,25$, text-fig. $2: 2$.

Coryphidium elegans Cramer, Allam, Kanes and Díez 1974. - Eisenack et al. 1976, pp. 147148.

*Coryphidium elegans Cramer, Allam, Kanes and Díez 1974 ; Díez and Cramer 1977, p. 10, 30.

?Coryphidium elegans Cram. et al. - Kalvacheva 1979, p. 1399, pl. 1 : fig. 10.

*Coryphidium elegans Cram. et al. - Molyneux 1979, pp. 417, 419.

*Coryphidium elegans Cram. et al. - Kalvacheva 1980, p. 196.

? Coryphidium cf. elegans Cram. et al. 1974. - Cocchio 1981, pp. 76-77, 98, text-fig. 50.

*Coryphidium cf. elegans Cramer, Allan, Kanes et Díez 1974. - Cocchio 1982, pp. $28,31$.

*Coryphidium elegans Cramer, Allam et al. 1974. - Turner 1982, pp. 122-123, 125.

Coryphidium elegans Cramer et al. 1974. - Downie 1984, text-fig. 4 : 18.

?Coryphidium elegans Cramer, Allam, Kanes and Díez 1974 ; Tongiorgi et al. 1984, p. 669, pl. 2, figs. 14, 15.

*Coryphidium elegans. - Baudelot and Fournier-Vinas 1984, p. 10. 
*Coryphidium elegans (Cram. , ...). - Fournier-Vinas 1985, p. 809.

* Coryphidium elegans Cramer, Allam, Kanes and Díez 1974. - Albani et al. 1985b, p. 12.

*Coryphidium cf. elegans Cramer, Allam, Kanes and Díez 1974. - Albani et al. 1985b, p. 13.

*Coryphidium elegans Cramer, Hallam, Kanes and Díez 1974 [sic]. - Albani et al. 1985b, p. 14

Coryphidium elegans Cramer et al. 1974. - Fang 1986, pp. 130, 132, 135, 139-141, 147, 157, pl. 4 : fig. 1.

? Coryphidium aff. elegans Cramer, Allam, Kanes and Díez. - Mette 1989, p. 3, 8, pl.1 : 24, pl. $2: 12,13,15$.

*Coryphidium elegans. - Mette 1989, p. 3-5, 8.

Coryphidium elegans Cramer, Allam, Kanes and Díez 1974 ; Albani 1989, p. 5, 14, 16, pl. 1 : figs. 26-29.

?Coryphidium elegans Cramer et al. - Li 1990, p. 142, 147, 157, pl. 2 : fig. 11.

?Coryphidium cf. elegans Cramer et al. 1974. - Cooper and Molyneux 1990, fig. 3 : p, q.

*Coryphidium elegans Cramer et al. 1974. - Cooper and Molyneux 1990, p. 152.

Coryphidium elegans Cramer et al. 1974. - Ghavidel-Syooki 1994, pl. 4 : figs. 10-12.

* Coryphidium elegans Cramer et al. 1974. - Fensome et al. 1990, p. 155.

*Coryphidium elegans. - Fensome et al. 1991, p. 31.

* Coryphidium elegans Cramer, Allam, Kanes and Díez 1974. - Millward and Molyneux 1992, p. $81,83,85$.

Coryphidium elegans Cramer et al. 1974. - Tongiorgi et al. 1994, p. 596-597, 599, 603, pl. 2 : fig. 6.

Coryphidium elegans Cramer et al. 1974. - Ghavidel-Syooki 1994, pl. 4 : figs. 11-12.

Coryphidium elegans Cramer et al. 1974. - Ghavidel-Syooki 1995, pl. 1 : fig. 8.

*Coryphidium cf. elegans. - Cooper et al. 1995, p. 190.

Coryphidium cf. elegans Cramer et al. 1974. - Martin 1996, 6-7, 12, pl. 1 : fig. 16.

Coryphidium sp. aff. C. elegans. - Molyneux 1996, p. 546-548.

*Coryphidium elegans. - Ghavidel-Syooki 1997, p. 390.

Coryphidium sp. aff. C. elegans. - Molyneux and Leader 1997, p. 81, 83-93, pl. 1 : figs. 1-6.

Coryphidium elegans Cramer, Allam, Kanes and Díez 1974. - Connery and Higgs 1999, p. 136, 142, 144, 150, pl. 2, fig. 5.

Coryphidium sp. cf. elegans Cramer, Allam, Kanes and Díez 1974. - Connery and Higgs 1999, p. 136, 142, 144, pl. 2, fig. 6.

Coryphidium sp. aff. elegans Cramer, Allam, Kanes and Díez 1974 sensu Molyneux and Leader 1997. - Connery and Higgs 1999, p. 136, 142, pl. 2, fig. 8.

Coryphidium elegans Cramer, Allam, Kanes and Díez 1974. - Quintavalle et al. 2000, p. 6, 9, pl. 1 : fig. 11.

Coryphidium elegans Cramer and Díez 1976 (sic). - Brocke et al. 2000, p. 28, 31-32, 37, pl. 2 : fig. 2.

Coryphidium bohemicum. - Todd et al. 2000, p. 829-830, fig. 10c.

Holotype : Cramer et al. 1974, p. 184, pl. 27 : fig. 16.

Type locality and type level : Boujad, Tadla Basin, Morocco, borehole BJ-109, 360m.

Original diagnosis (Cramer et al. 1974). "Central body hollow, subsquare with rounded corners. The vesicles are plate-like in form, much flatter than wide. The vesicle is covered by a combination of short filose sculptural elements and short, non-accidental, low rugulae. The distribution of these sculptural elements show areas of preference : the filose sculptural elements are concentrated at the corners of the body (each corner shows about the same 
sculptural density), and the rugulae are more abundant on the central portions of the body walls. The sculptural complexity, quantity, and size has been found to be quite variable from specimen to specimen in the same sample. The filose sculptural elements are essentially solid, slender and vary from flexible spines to hairs; occasionally they may show some kind of tiny knob at the extreme distal termination. These elements are up to about one micron thick (about one-half micron is normal) and up to ten microns long (but generally they are shorter : three to five microns is normal). At their bases they are a bit wider : up to three microns; they taper rapidly. The rare knobs are about one micron in diameter in all directions. The rugulate elements are about one micron both high and wide, two or three microns apart and of variable length. Generally they are about ten microns long. The vesicle wall is about one micron thick. Mode of opening not known; no endodermal structures observed.

Remarks: Coryphidium elegans is the second most frequently recorded species after $C$. bohemicum with citations in over 30 publications. The rather long diagnosis indicates that most specimens have long (up to $10 \mu \mathrm{m}$ ), simple processes with undivided distal tips, which differentiate this species from Vavrdová's (1972) C. bohemicum. On the other hand, however, the presence of simple processes makes an emendation of the generic diagnosis necessary. The specimens attributed to $C$. elegans in literature also show a wide range of process morphologies, but usually the name $C$. elegans was given to specimens with longer processes than those of $C$. bohemicum.

Biostratigraphical and palaeobiogeographical distribution: C. elegans has also been reported from numerous localities in the Lower and Middle Ordovician of Europe and southern China (see biostratigraphy and palaeobiogeography chapters).

\section{Coryphidium ? longispinosum Gao 1991}

Coryphidium longispinosum (sp. nov.). - Gao Lianda 1991, p. 446, 451, 454, 455, pl. 2, fig. 10.

Holotype : Gao Lianda 1991, p. 451, pl. 2 : fig. 10.

Type locality and type level: Wuding (Yunnan Province, China), Hongshiyan Formation, sample W-3.

Translation of the original description and of the comparison.

Original diagnosis (translated from Chinese): The vesicle is more or less sub-quatrate, sometimes circular in outline. The wall is thick and yellowish brown in color. The corners are round and the four sides are concave, tending to go inside (sic). The surface of the vesicle has long appendices, which are more frequent at the corners. The bases of the appendices are not in contact. Length of the appendices: $8-20 \mu$; the distal end of the spines is round or tapering. Central body diameter : $25-26 \mu$.

Comparison : The new species based on samples collected from the Yunnan province is similar in outline to C. bohemicum established from the early Ordovician (Arenigian stage) of Czechoslovakia, Bohemia, by Vavrdová (1972, p. 84-85, pl. 1 : fig. 1-2).

The difference is that the vesicle of the latter $(C$. bohemicum) is quadrate and has round corners, and some very fine lines are parallel to the four sides. At the corners and the four sides, a lot of densely distributed, small conical spines $(2-3 \mu)$ are present. 
Remarks : It is not clear if this species really belongs to Coryphidium. There is no evidence from the illustration of the holotype for the presence of the structural ridges, and neither are such structures mentioned in the diagnosis. On the contrary, in the comparison with $C$. bohemicum, Gao (1991) indicates that the latter species differs from longispinosum in displaying "fine lines". We therefore only questionably attribute Gao's (1991) new species to Coryphidium. The species has never been recorded since its original description, although a great number of other workers have analysed samples from the same area and stratigraphical interval ( $\mathrm{Li}$ et al. 2003).

\section{Coryphidium miladae Cramer and Díez 1976}

Coryphidium milada n.sp. - Cramer and Díez 1976, p. 205, text-fig. 2 : 6, pl. 23, figs. 9, 14, $22,23$.

Coryphidium milada Cramer and Díez 1976. - Eisenack et al. 1979, p. 83.

*Coryphidium cf. milada Cr. and Díez. - Kalvacheva 1982a, p. 1103.

?Coryfidium cf. milada Cramer and Díez 1969 (sic). - Kalvacheva 1982b, pl. 1 : fig. 7.

?Corypbidium cf. milada Cr. and Díez (sic). - Kalvacheva 1982b, pl. 2 : fig. 7.

* Coryphidium cf. milada Cr. and Díez (sic). - Kalvacheva 1982b, p. 18.

?Coryphidium milada Cramer and Díez 1976. - Tongiorgi et al. 1984, p. 669, pl. 2 : fig. 16.

* Coryphidium milada (Cr.Díez). - Fournier-Vinas 1985, p. 809.

?Coryphidium cf. C. milada Cramer and Díez 1976. - Albani et al. 1985a, p. 50, 51, 60, pl. 6, fig. 9.

?Coryphidium milada Cramer e Díez 1976. - Albani et al. 1985b, p. 12, pl. 3, figs. 14, 15.

*Coryphidium cf. milada Cr. and Díez. - Kalvacheva 1986, p. 40.

?Coryphidium milata Cramer et al. 1967 (sic). - Fang 1986, p. 132,133, 147, pl. 4 : figs. 3, 4.

*Coryphidium milada. - Fang 1986, p. 135, 139, 140.

Coryphidium milada Cramer and Díez 1976. - Albani 1989, p. 5, 16, pl. 2 : figs. 2-3.

*Coryphidium cf. milada Cramer and Díez 1976. - Mette 1989, p. 7.

?Coryphidium milada. - Vavrdová 1990b, p. 243.

*Coryphidium miladum Cramer and Díez 1976. - Fensome et al. 1990, p. 155.

*Coryphidium miladum. - Fensome et al. 1991, p. 61.

?Coryphidium milada. - Reitz 1994, p. 664, pl. 1, fig. 20.

Coryphidium miladae Cramer and Díez 1976. - Tongiorgi et al. 1994, p. 596, 598-599, 603, pl. 2 : fig. 5.

Coryphidium miladae - Coryphidium tadla group. - Rubinstein et al. 1999, p. 270-272, 274, pl. 3 : figs. 3,7 , pl. 5 : fig. 4.

*Coryphidium miladae - Coryphidium tadla group sensu Rubinstein in Rubinstein et al. 1999. - Rubinstein and Toro 2001, p. 426, 428.

Holotype : Cramer and Díez 1976, p. 205, pl. 23 : fig. 9.

Type locality and type level : Boujad, Tadla Basin, Morocco, borehole BJ-109, 510m.

Original diagnosis (Cramer and Díez, 1976). "Species of Coryphidium of a similar morphology to that of $C$. elegans, but distinguished from it in that $C$. milada is smooth or has no distinct rugulate sculpture and that its filose elements are few, and rather widely spaced. These elements are in the form of thin bacula; some of them are sharp-tipped, others bifurcated distally, and still others truly club-shaped". 
Nomenclatural note : $C$. milada is here corrected to $C$. miladae, since Milada is a personal name, the genitive inflection must be miladae (I.C.B.N., Article 60).

Remarks : As discussed above in the discussion of $C$. australe and C. tadlanum, two other of the seven 'new' Coryphidium species of Cramer and Díez (1976) are readily undistinguishable. $C$. miladae and $C$. tadlanum are diagnostified and illustrated in the publication of their original description with very close morphologies. Rubinstein in Rubinstein et al. (1999) created the informal "Coryphidium miladae - Coryphidium tadlum group". She presented a first synonymy list including both taxa from the original description of Cramer and Díez (1976) and the specimens determined as C. milada and C. tadla by Tongiorgi et al. (1984). We agree with Rubinstein that "no essential difference can be detected" between these two taxa (see also discussion below).

Biostratigraphical and palaeobiogeographical distribution: Perhaps because of its imprecise original description, $C$. miladae has only been reported from a few localities. Its distribution does not differ from that of the other species of the genus (see biostratigraphy and palaeobiogeography chapters).

\section{Coryphidium minutum Cramer and Díez 1976}

Coryphidium minutum n.sp. - Cramer and Díez 1976, p. 205, text-fig. 2 : 7, pl. 23 , figs. 7, 10. Coryphidium minutum Cramer and Díez 1976. - Eisenack et al. 1979, p. 85.

?Coryphidium minutum Cramer et Díez 1976. - Marhoumi et al. 1982, p. 139, pl.1, figs. 1920.

*Coryphidium cf. minutum Cr. and Díez. - Kalvacheva 1982a, p. 1103.

*Coryphidium cf. minutum Cr. and Díez ; Kalvacheva 1982b, p. 18.

*Coryphidium cf. C. minutum Kramer e Díez 1976 (sic). - Albani et al. 1985b, p. 14.

*Coryphidium minutum (Cr. Díez). - Fournier-Vinas 1985, p. 809.

* Coryphidium cf. minutum Cr. and Díez ; Kalvacheva 1986, p. 40.

? ?Coryphidium minutum Cramer et Díez 1976. - Molyneux, p. 324, text-fig. 19.

?Coryphidium cf. minutum Cramer and Díez 1976 ; Arriagha e Cunha and Vanguestaine 1989, p. 72, 74, pl. 1 : fig. 11.

*Coryphidium cf. minutum Cramer and Díez 1976. - Mette 1989, p. 7.

Coryphidium minutum Cramer and Díez 1976. - Albani 1989, p. 5, 16, pl. 2 : fig. 1.

*Coryphidium minutum Cramer and Díez 1976. - Fensome et al. 1990, p. 156.

*Coryphidium minutum. - Fensome et al. 1991, p. 62.

?Coryphidium minutum Cramer and Díez 1976. - Reitz and Höll 1991, p. 331, 334, pl. 2 : fig. 4.

*Coryphidium minutum Cramer and Díez 1976. - Reitz and Höll 1992, p. 199.

Coryphidium minutum Cramer and Díez 1976. - Tongiorgi et al. 1994, p. 596, 598-599, 603, pl. 2 : fig. 3.

Coryphidium minutum Cramer and Díez 1976. - Ghavidel-Syooki 2001, p. 20, pl. 3 : fig. 8.

Holotype. Cramer and Díez 1976, p. 205, pl. 23 : fig. 7.

Type locality and type level. Boujad, Tadla Basin, Morocco, borehole BJ-109, 510m.

Original diagnosis (Cramer and Díez 1976). "Species of Coryphidium of a similar general morphology to that of $C$. elegans, but distinguished from it in that $C$. minutum is entirely 
smooth and displays a sculpture consisting of numerous tiny filose elements. These vary from aculeate to flagellate. Some are capitate".

Remarks: The original diagnosis of this species indicates that it lacks ridges ("entirely smooth") and so it should not be included in the genus Coryphidium. The processes of this morphotype are very small ("filose elements"). Coryphid acritarchs with such small processes have been recorded by several authors. The boundaries between $C$. minutum and other species with very small processes $(C$. almohadillum, $C$. barakum) are not clear. The processes are very similar, but some species have ridges/striations on the vesicle.

Biostratigraphical and palaeobiogeographical distribution: Perhaps because the original description of this species is not very precise, and the distinction between this and other taxa not clearly defined, $C$. minutum has not been recorded many times. Similarly to other species, its distribution falls withing the biostratigraphical and palaeobiogeographical ranges of the genus Coryphidium (see biostratigraphy and palaeobiogeography chapters).

\section{Coryphidium ? persianum Ghavidel-Syooki 1990 (invalid species)}

Coryphidium persica n.sp. - Ghavidel-Syooki 1990, p. 172, pl. 4 : figs 1-4.

*Coryphidium persica. - Ghavidel-Syooki 1997, p. 390.

Holotype. No holotype has been designated, but four specimens were illustrated (GhavidelSyooki 1990, p. 172, pl. 4 : fig. 1-4). It is not clear where the type material is deposited.

Type locality and type level. Upper part of the Zard Kuh Formation, type level not precisely indicated.

Original diagnosis (Ghavidel-Syooki 1990). "Central body is typically quadrate to subquadrate with rounded corners. The vesicle is covered by a translucent membrane. The membrane is square shape that it is connected to the body by a set of filose processal elements. The filose processal elements are slender, solid and vary from flexible spines to hairs. This species ranges from 50-60 microns (including membrane and body). The body is 25 to 30 microns and the membrane is 10 to 15 microns. No endodermal structure and no mode of opening is recognizable".

Remarks: This species was described in its original diagnosis as lacking the ridges characteristic of the genus Coryphidium. In addition, the presence of a membrane is inconsistent with the original and emended diagnoses of the genus (membranes have never been reported so far).

As no holotype has been designated, the species is currently invalid (Art. 37. of the I.C.B.N.). The name has corrected here from Coryphidium persica to $C$. persianum, following recommendation $60 \mathrm{D}$ of the I.C.B.N. (the specific epithet is derived from a geographical name, "Persia").

Biostratigraphical and palaeobiogeographical distribution: The species has only been recorded so far from the upper part of the Zard Kuh Formation in southern Iran. 
Coryphidium ramiferum Cramer and Díez 1976

Coryphidium ramiferum n.sp. - Cramer and Díez 1976, p. 206, text-fig. 2 : 8, pl. 23, figs. 16, 24.

Coryphidium ramiferum Cramer and Díez 1976. - Eisenack et al. 1979, p. 87.

*Coryphidium ramiferum Cramer and Díez 1976. - Fensome et al. 1990, p. 156.

*Coryphidium ramiferum. - Fensome et al. 1991, p. 82.

Holotype. Cramer and Díez 1976, p. 206, pl. 23 : fig. 16.

Type locality and type level. Boujad, Tadla Basin, Morocco, borehole BJ-109, 510m.

Original diagnosis (Cramer and Díez 1976) : "Species of Coryphidium of a similar general morphology to that of $C$. elegans, but distinguished from it in that $C$. ramiferum has an indistinct sculpture of widely spaced rugulate elements and bears numerous ramified processes. These processes are short and plump and branch into a crown some about palmate pinnae of varying length".

Remarks: Clearly belonging to the genus Coryphidium, this species is characterized by processes with a typical crown-like distal termination. It has never been recorded since its original description.

Biostratigraphical and palaeobiogeographical distribution: The species is so far only known from the type-level in the Tadla Basin, Morocco.

\section{Coryphidium tadlanum Cramer and Díez 1976}

Coryphidium tadla n.sp. - Cramer and Díez 1976, p. 206, text-fig. 2 : 9, pl. 23, figs. 3, 4, 15, $18,19$.

Coryphidium tadla Cramer and Díez 1976. - Eisenack et al. 1979, p. 89.

* Coryphidium tadla Cramer and Díez 1976. - Fournier-Vinas 1978, p. 266.

?Coryphidium tadla Cramer and Díez 1976. - Cocchio 1981, p. 75, 98, text-fig. 49.

* Coryphidium tadla Cramer and Díez 1976. - Cocchio 1982, p. 28.

* Coryphidium tadla (Cr. Díez). - Fournier-Vinas 1985, p. 809.

*Coryphidium tadla. - Fang 1986, p. 135.

Coryphidium tadla Cramer and Díez 1976. - Albani 1989, p. 5, 16-17, pl. 2, figs. 4-5.

* Coryphidium tadlum Cramer and Díez 1976. - Fensome et al. 1990, p. 156.

*Coryphidium tadlum. - Fensome et al. 1991, p. 97.

Coryphidium miladae - Coryphidium tadla group. - Rubinstein et al. 1999, p. 270-272, 274, pl. 3 : figs. 3,7 , pl. 5 : fig. 4.

*Coryphidium miladae - Coryphidium tadla group sensu Rubinstein in Rubinstein et al. 1999. - Rubinstein and Toro 2001, p. 426, 428.

Coryphidium tadla Cramer, Allam, Kanes and Díez 1974. - Quintavalle et al. 2000, p. 6, 9, pl. 1 : fig. 7.

Holotype. Cramer and Díez 1976, p. 206, pl. 23 : fig. 16.

Type locality and type level. Boujad, Tadla Basin, Morocco, borehole BJ-109, 510m. 
Original diagnosis (Cramer and Díez 1976). "Species of Coryphidium of a similar general morphology to that of $C$. elegans, but distinguished from it in that $C$. tadla has no rugulae and practically all the filose processes are capitate ; furthermore, only a few of them dichotomize at the extreme end of the processes. The distal expansions are often clearly elongated and spoon-shaped. The filose elements are markedy more abundant than in C. elegans".

Nomenclatural note: Coryphidium tadla is corrected here into C. tadlanum, because the locality were the new species is found (Tadla) is a geographical name (I.C.B.N., Article 60).

Remarks: This original diagnosis of this species describes it as lacking the rugulae (ridges/striations), which is inconsistent with the original diagnosis of the genus. However, although Cramer and Díez (1976) mentioned the absence of rugulae in the diagnosis, on the holotype (Cramer and Díez 1976, pl. 23, fig. 4), the fine ridges are clearly visible on the vesicle wall. Coryphidium tadlanum was placed in synonymy with $C$. miladae by Rubinstein in Rubinstein et al. (1999).

Biostratigraphical and palaeobiogeographical distribution: The species is so far only known from the type-level in the Tadla Basin, Morocco.

\subsection{Morphological variation within Coryphidium species and its taxonomic treatment}

From a review of the literature, and in particular from a critical analyses of the diagnoses in Cramer et al. (1974) and Cramer and Díez (1976), it appears that most species of Coryphidium are not clearly defined and that it can be difficult to distinguish between them. In addition, none of the authors that have erected new taxa have discussed in detail the morphological characteristics that allows a distinction of the newly defined species from all previously described taxa. In particular, the descriptions of the seven new species of Cramer and Díez (1976) are almost impossible to understand, because the original diagnoses correspond with neither with the text-figures, nor with the microphotographs in the plate.

The bibliographical review of Coryphidium shows that many authors have had difficulties in assigning their specimens to published species. Several authors have used open nomenclature, including "cf." and "aff.", in their determinations. Vecoli (1999) considered Coryphidium australe from $C$. miladae as "possibly conspecific". Rubinstein in Rubinstein et al. (1999) has noted that it is impossible to distinguish Coryphidium miladae from $C$. tadlanum. In addition, as indicated above, it is also difficult to distinguish C. almohadillum and $C$. barakum, both species being described with very short ornaments (shorter than $1 \mu \mathrm{m}$ and $0.5 \mu \mathrm{m}$, respectively). Coryphidium minutum is also very similar to these two latter species, but Cramer and Díez (1976) erected a new species for this morphotype, because they did not observe the fine ridges with the optical microscope.

In summary, nine species can currently be considered to be validly published species of the genus Coryphidium. Two other species, C. ? longispinosum and C.? persianum possibly belong to it, although the latter species is not valid. The nine Coryphidium species (C. almohadillum, C. australe, C. barakum, C. bohemicum, C. elegans, C. miladae, C. minutum, $C$. ramiferum, $C$. tadlanum) all have the body outline typical of coryphid acritarchs, and all have vesicles of about the same size (length of the sides between 20 and $35 \mu \mathrm{m}$ ). They always show fine ridges (also called rugulae) on their wall, which are parallel to the vesicle border and that cover the entire body. These ridges are not always clearly visible or have not always been described, however, which might be the result of preservation or simply due to observation techniques. 
The nine Coryphidium species show a wide morphological variability which is expressed mainly in process length and structure. So, whereas $C$. bohemicum is described as having heteromorphic processes of varying degrees of complexity, the diagnosis of C. elegans states that it has simple, distally tapering processes with sharp-pointed tips. Nevertheless, both Vavrdová (1972) and Cramer et al. (1974) accepted a wide variability for their species in the diagnoses. The seven other species of Cramer and Díez (1976) are also distinguished on the basis of different process types and sizes. If we accept a wide variation of process lengths and structures of $C$. bohemicum, all specimens could fall within the diagnosis of this species and all other taxa could be considered as junior synonyms of the type species. If, however, we consider every variation as taxonomically significant, we could consider all species as separate taxonomic entities.

The problem is how to deal taxonomically with the morphological variability exhibited between Coryphidium species. Servais and Eiserhardt (1995) indicated that transients may exist between previously described, clearly distinguishable taxa in the galeate acritarch plexus. Based on this study, Servais and Molyneux (1997, p. 118-119) discussed the taxonomical treatment of variability in acritarch morphotypes, including the galeates, and indicated that the great morphological variability of acritarchs presents a taxonomic problem. If the variability is discontinuous, it is straightforward to identify two different morphotypes as two separate taxa, and so, for example, to erect two separate species. However, if a continuous variability exists between two end-members of a larger population, it is usually not possible to draw limits between the morphotypes, and it is therefore very difficult , if not impossible, to define separate taxa. As indicated by Servais and Molyneux (1997), acritarch taxonomy needs to maintain a balance between two opposing tendencies. On the one hand, acritarch morphotypes that grade from one to the other ought to be included in the same taxon. On the other hand, different morphologies may provide information that is useful to earth science, especially for biostratigraphy, palaeoobiogeography or palaeoecology. If the different morphotypes ar subsumed into the same taxon, the biostratigraphical or other information could be lost.

Although material from several localities and regions has been analysed for the present study, it is not possibly to make clear distinctions between the species defined in the literature, and it is sometimes difficult to attribute a species name to a specimen. However, it is clear that some morphotypes are biostratigraphically useful, at least at a local or regional scale. As our view of the genus is not complete, we have therefore avoided makiing new taxonomic decisions, and we retain the existing taxonomy, despite the inherent.

\section{Palaeoecology and palaeobiology}

It is difficult to judge the biological significance of the morphological variability of acritarchs and to determine which aspect of variability is phenotypic and which is genotypic. As Palaeozoic acritarchs are usually considered to represent the cysts of organic-walled microphytoplankton, it is interesting to compare their morphological variability with that of Recent dinoflagellate cysts. In the last decade, studies on the formation of dinoflagellate cysts in culture experiments has shown that the morphology of the resting cysts is controlled by both temperature and salinity (Kokinos and Anderson 1995, and references therein). The results indicate that process length and process structure are salinity and temperature dependent. Short-spined dinoflagellate cysts are usually related to low salinity environments, and long processes can be related to higher salinities.

From these results of experiments on cultured dinoflagellate cysts, and also from palaeontological observations (e.g. Turon 1982, Ellegaard 2000), it appears that process 
length provides a quantifiable record of past salinity levels. The models that arise from these observations can possibly be applied to Cenozoic sediments, but it will probably be more difficult to establish relationships between process length and salinity in older rocks. Interestingly, Cramer and Díez (1976, p. 203) wrote that "Coryphidium might indicate paleaosalinities which are slightly higher than normal (i.e. normal = oceanic)", although they provided no arguments to support for this interpretation.

As yet, it is not possible to indicate the palaeoecological attributes of the genus Coryphidium and its species. Li et al. (2004) observed the genus in all samples and from all localities along an inshore-offshore transect in the Early-Middle Ordovician of the Yangtze Platform, southern China. Coryphidium is present from nearshore environments, displaying very low overall diversities (less than 10 acritarch species recorded), across the platform to offshore environments with the highest diversities (with about 40 acritarch species). Although quantitative studies, including biometrical studies of the processes, have not been completed at the specific level, it seems that Coryphidium morphotypes do not change across the Yangtze Platform. Specimens that can be attributed to $C$. bohemicum (displaying a large variety of processes up to $5 \mu \mathrm{m}$ ) have been recorded on both the carbonate platform (e.g. Li 1987) and in nearshore environments (e.g. Li and Yuan 1995).

\section{Biostratigraphy}

\subsection{Stratigraphical distribution of the type material of Coryphidium}

Coryphidium has been recorded in some 100 publications, from numerous localities in Europe, North Africa, Asia, Newfoundland and Argentina. However, only a few samples have been precisely dated by means of other fossil groups (graptolites, chitinozoa, trilobites, etc.).

Although attributed to the Arenig, Vavrdová's (1972) type material has never been dated precisely. The sample is considered to come from the upper part of the Klabava Formation from a level equivalent to the regional Tetragraptus reclinatus abbreviatus graptolite Biozone. This regional biozone is now renamed Azygograptus ellesi - Tetragraptus reclinatus abbreviatus graptolite Biozone (Kraft and Kraft 1999, 2003). According to the discussion in Martin (1982), this zone should correspond to the combined Isograptus gibberulus and Didymograptus hirundo graptolite Biozones in the British Isles (see also Tongiorgi and Di Milia 1999, fig. 1). C. bohemicum has been recorded from several stratigraphical levels by Vavrdová (1972, 1974, 1976, 1977, 1982a, 1982b, 1986, 1988, 1989, 1990a, 1990b, 1997), ranging from the regional Corymbograptus v-similis graptolite Biozone (equivalent of the upper part of the British varicosus graptolite Biozone) to the Upper Ordovician ; the higher occurrences are considered to be the result of reworking (Vavrdová 1982). In the Czech Republic, Coryphidium is thus considered to range from the lower (but not lowermost) Arenig through the lower Llanvirn.

The type material of Cramer et al. (1974) and Cramer and Díez (1976) is from the borehole Boujad (BJ) 109, from depths of $360 \mathrm{~m}$ (Cramer et al. 1974) and $510 \mathrm{~m}$ (Cramer and Díez (1976). Parts of this borehole have been dated by Soufiane and Achab (1993) using chitinozoans. A late Arenig age can clearly be attributed to the sample from $510 \mathrm{~m}$, based on the presence of Desmochitina bulla between 512 and $481 \mathrm{~m}$, but the sample from $360 \mathrm{~m}$, which contained the holotype of $C$. elegans, is from an interval that is not dated by chitinozoans, and may be of late Arenig or younger age.

\subsection{Biostratigraphically controlled occurrences of Coryphidium}


It is not surprising that the genus was considered for many years to be typical of the Arenig and Llanvirn (e.g. Martin 1982), because most occurrences are from that time interval. Precisely dated occurrences in the Arenig and Llanvirn are available from China, Avalonia, the southern European - North African border of peri-Gondwana, and Argentina.

In southern China the genus has been recorded from the Chinese D. deflexus and A. suecicus graptolite biozones of late Yushanian (late early Arenig) age (e.g. Li 1987) up to the Chinese D. murchisoni Biozone of late Darriwilian (late Llanvirn) age (e.g. Li et al. 2000). As in the Czech Republic, the genus has not yet been recorded in China from the lowermost Arenig.

Several sections from Avalonia that have yielded Coryphidium are dated by means of other fossil groups. The occurrence in the Wabana Group of Newfoundland ("western Avalonia") indicates a probable early Arenig age ("D. extensus Zone" according to Dean in Dean and Martin 1978). The stratigraphical range of Coryphidium in Belgium is now better constrained due to recent graptolite and chitinozoan studies. The occurrence in the Villers-laVille Formation in the Brabant Massif (Martin 1977) is now considered to be of middle Arenig age (Samuelsson and Verniers 2000), while the age of the Rigenée Formation in the Brabant Massif, which also yielded Coryphidium (Servais 1991), is now considered to span the latest Arenig and early Llanvirn, but certainly includes the early Llanvirn $D$. artus biozone (Maletz and Servais 1997, Samuelsson and Verniers 2000). Coryphidium specimens are also found in the Caradoc (e.g. Martin et al. 1970) and in the Lower Devonian (Steemans 1989) of Belgium, but these occurrences are considered to be the result of reworking. In Germany, Coryphidium is found at levels that are clearly dated as being of early and middle Llanvirn (Darriwilian), D. artus and D. murchisoni graptolite Biozone age (Burmann 1970, Maletz and Servais 1993, Servais 1994, Servais et al. 2001).

Occurrences of Coryphidium spp. in the Lake District of northwest England are generally well dated by graptolite faunas that occur in the same beds (Cooper et al., 2004). The earliest specimens of Coryphidium, including the morphotype Coryphidium aff. elegans of Molyneux and Leader (1997) are from the Watch Hill Formation of the Skiddaw Group, which is correlated with the latest Tremadocian Araneograptus murrayi Biozone based on the presence of the eponymous graptolite species. The murrayi Biozone of the Lake District is equivalent to the Araneograptus murrayi and Hunnegraptus copiosus graptolite biozones of the Baltoscandian succession. Coryphidium aff. elegans ranges into the overlying Hope Beck Formation, reaching a level that is probably in the lowest Arenig Tetragraptus phyllograptoides graptolite Biozone. Specimens assigned to Coryphidium bohemicum appear in the Hope Beck Fomration, reaching a level that is probably in the lowest Arenig Tetragraptus phyllograptoides graptolite Biozone or in the overlying Didymograptus varicosus graptolite Biozone, and range into the upper Arenig Isograptus victoriae graptolite Biozone in the Kirk Stile Formation, if not higher. The Coryphidium aff. bohemicum morphotype of Molyneux and Leader (1997) occurs in the upper part of the Kirk Stile Formation, at a level assigned to the upper Arenig Isograptus gibberulus and Aulograptus cucullus biozones. Coryphidium aff. bohemicum occurs at the same locality as graptolites of the highest Arenig cucullus Biozone in the northern Lake District. Specimens of Coryphidium also occur in the lower Llanvirn Didymograptus artus Biozone in the Lake District (Booth, 1979). Booth (1979) recorded specimens of Coryphidium, assigned to Coryphidium bohemicum and Coryphidium elegans, from sections along the southern shore of the Menai Straits from Bangor to Caernarvon in North Wales. The beds in these sections comprise the lowest part of the Nant Ffrancon Group, ranging here from middle Arenig to Llanvirn in age. Molyneux (1987) recorded poorly preserved specimens assigned to Coryphidium bohemicum from the Stapeleyella abyfrons and Bergamia rushtoni trilobite biozones of the Fennian (upper Arenig) Pontyfenny Formation in south Wales, and a specimen assigned to 
Coryphidium minutum from the lower (but probably not lowest) Arenig Allt Cystanog Member of the Ogof Hên Formation. Turner (1982) recorded Coryphidium australe, $C$. bomemicum and $C$. australe from the type Caradoc Series of the Ordovician in the Welsh Borders, where they were considered to be reworked.

Independently dated occurrences of Coryphidium from North Africa are from the borehole N12 in northern Algeria (Vecoli 1999) and from borehole A1-70 in the Ghadamis Basin in NW Libya (Vecoli and Quintavalle, unpublished). These levels were dated with chitinoans as belonging to the late Arenig.

Recent studies from Argentina (Rubinstein et al. 1999, Rubinstein and Toro 2001) indicate the occurrence of Coryphidium sp. in the Tetragraptus akzharensis graptolite Biozone of early (but not earliest) Arenig age, and of the Coryphidium miladae-tadlanum group, Coryphidium cf. C. bohemicum and Coryphidium australe in the Didymograptellus bifidus graptolite Biozone of middle Arenig age.

Most of the other occurrences of Coryphidium are not precisely dated, and age information is generally only provided by the accompanying acritarch assemblages. Records of "Arenig-Llanvirn" Coryphidium occurrences include those of Marhoumi et al. (1982) from Morocco, Smith (1981) and Maziane et al. (2000) from Ireland, Arriagha e Cunha and Vanguestaine (1988) from Portugal, Rauscher (1974a, 1974b), Fournier-Vinas and Donot (1977), Fournier-Vinas (1978) and Cocchio (1981, 1982) from France, Reitz and Höll (1991, 1992) and Reitz (1994) from Austria, Albani et al. (1985b) from Hungary, Tongiorgi et al. (1984), Albani et al. (1985a) and Albani (1989) from Sardinia (Italy), Kalvacheva (1979, 1980, 1982a, 1982b, 1986) from Bulgaria, Ghavidel-Syooki (1990, 1997, 2001) from Iran, and Tongiorgi et al. (1994) and Quintavalle et al. (2000) from Pakistan.

\subsection{First appearance of the genus Coryphidium}

Of great interest for international correlations is the First Appearance Datum (FAD) of the genus Coryphidium, which is now established as being in the late Tremadocian. The first occurrence of Coryphidium in sections in the British Isles is in the messaoudensis-trifidum acritarch assemblage (Cooper et al., 2004), at a level that correlates with the late Tremadoc Araeograptus murrayi graptolite Biozone (see above).

Servais and Mette (2000) reinvestigated the messaoudensis-trifidum acritarch assemblage of the Barriga Shale Formation in south-western Spain. Coryphidium morphotypes, which can not be attributed to species, are present in this formation, although in very low numbers, in the late Tremadocian Araneograptus murrayi and Hunnegraptus copiosus graptolite biozones.

Preliminary results from new investigations in northwestern Argentina also indicate that the first appearance of Coryphidium in that area is in strata correlated with the Araneograptus murrayi Biozone (Rubinstein and Toro 2002, Rubinstein 2003).

Specimens of Coryphidium are also present in the messaoudensis-trifidum acritarch assemblage of the uppermost Jalhay Formation in the Stavelot Inlier, Belgium, that can also be dated as bein of late Tremadocian age (Vanguestaine and Servais, 2002). However, Coryphidium has note been recorded from the messaoudensis-trifidum assemblage in the Varnkevitz Formation from the subsurface of the island of Rügen (Servais and Molyneux 1997).

In summary, the genus Coryphidium appears in the late Tremadocian, but most records are from Arenig and younger strata, this might reflect the relatively few studies on acritarchs from latest Tremdocian strata. Most records are from Arenig and Llanvirn sequences on the periphery of the Gondwana supercontinent. The last occurrence of the genus is not precisely 
known, because records from the Upper Ordovician are generally attributed to reworking (e.g. Vavrdová 1982, Turner 1982).

\subsection{Stratigraphical significance of Coryphidium morphotypes}

Although taxonomical problems clearly exist, and although the boundaries between the different species are difficult to draw (see above), it appears that different morphotypes may have a stratigraphical significance, that may be useful, at least at a local or regional level. The first Coryphidium specimens in the late Tremadocian do not yet display the complex morphology characteristic of the classical bohemicum morphotype that was described by Vavrdová (1972). In the late Tremadocian, the first coryphids have been attributed to morphological transients between the genera Acanthodiacrodium and Coryphidium (e.g. Servais and Mette, 2000). In the latest Tremadocian and lowest Arenigian, specimens of Coryphidium always display relatively short processes with usually undivided distal ends. Morphotypes comparable to Vavrdová's (1972) holotype appear to be typical for middle Arenig levels. Such specimens with clearly heteromorphic processes and a well differentiated sculpture of ribs on the vesicle wall have been recognised all around the Gondwanan margin in levels that can be attributed to the middle Arenigian. In the late Arenigian, such morphotypes become rare, but variability is great, as documented in Cramer and Díez (1976). In the Llanvirnian, specimens attributable to still exist. They have a more rounded vesicle with usually plump processes, as described by Burmann (1970) as Baltisphaeridium obtusatum.

In most areas where Coryphidium has been found, complete sections from the late Tremadocian into the early Llanvirn are not observed, so that the evolution of the morphology of the genus is not fully understood. Nevertheless, the observation of different morphotypes in the sections of England and Wales lead to the understanding of a stratigraphical succession of morphotypes that seems to have a stratigraphical significance at a local scale.

\section{STEWART'S TEXT HERE}

\section{Palaeobiogeography}

As indicated by previous authors, Coryphidium is very important from a palaeobiogeographical point of view. Li (1989) observed the genus in his assemblages from South China together with the genus Striatotheca and the species Arbusculidium filamentosum, that all were considered typical for assemblages described from western and southern Europe and northern Africa. Therefore, Li (1989) attributed his South Chinese assemblages to the 'palaeoprovince' that was then named "Mediterranean province", following Vavrdová's (1974) distinction of two 'palaeoprovinces' in Europe. Li (1989) redefined this province by the presence of the three taxa Coryphidium, Striatotheca and Arbusculidium filamentosum. This province was subsequently renamed peri-Gondwanan acritarch 'palaeoprovince' (for a full historical overview, see Servais et al. 2003). The genus Coryphidium and in particular the type species were considered palaeobiogeographically so significant that Ghavidel-Syooki (1990) and Vavrdová (1997) described a 'Coryphidium bohemicum province' and a 'Coryphidium bohemicum acritarch bioprovince', respectively.

The comprehensive literature revision presented in the present work allows to provide a detailed plotting of all Coryphidium occurrences on a palaeobiogeographical reconstruction. Text-figure 1 clearly illustrates that Coryphidium is present all around the southern margin of 
hte supercontinent of Gondwana. From the occurrences on the Yangte Platform in southern China at almost equatorial position in western Gondwana, the genus is distributed all around the southern part of Gondwana, including high latitudes, and the distribution continues towards lower latitudes on the eastern side of the supercontinent, where the genus is recorded from localities such as Argentina. The genus was never recorded from the continents located at low latitutes, such as Laurentia, Siberia and Baltica, but also not from Lower-Middle Ordovician successions of northern Gondwana, such as Australia or North China.

Occurrences from southern China were recorded by many authors working in successions of the Yangtze Platform, including Fang (1986), Li (1987, 1990, 1991), Li and Yuan (1995, 1997, 1998), Yin (1995), Tongiorgi et al. (1995), Brocke et al. (2000), Li et al. (2002, 2004). Tongiorgi et al. (1994) and Quintavalle et al. (2000) observed Coryphidium from Pakistan, while Ghavidel-Syooki (e.g. 1990, 1997, 2001) and Martin (1996) recorded the genus from Iran and Turkey respectively.

The North African occurrences include the localities analysed in Morocco (Cramer et al. 1974 ; Cramer and Díez 1976 ; Marhoumi et al. 1981), Algeria, Tunisia and Lybia (e.g. Vecoli 1999).

The genus was largely recorded from localities of peri-Gondwanan Europe, including successions in Spain (Mette 1989, Servais and Mette, 1990), Portugal (Arriagha e Cunha and Vanguestaine 1988), France (Rauscher 1974a, 1974b, Fournier-Vinas and Donot 1977, Fournier-Vinas 1978, and Cocchio 1981, 1982), the Czech Republic (Vavrdová 1972, 1974, 1976, 1977, 1982a, 1982b, 1986, 1988, 1989, 1990a, 1990b, 1997), Austria (Reitz and Höll 1991, 1992, Reitz 1994, Hungary (Albani et al. 1985b), Italy (Tongiorgi et al. 1984, Albani et al. 1985a, Albani 1989) and Bulgaria (Kalvacheva 1979, 1980, 1982a, 1982b, 1986)

Coryphidium was also recorded from numerous localities of Avalonia, including Newfoundland (e.g. Dean and Martin 1978), Ireland (Smith 1981, Connery and Higgs 1999, Maziane et al. 2000, and Todd et al. 2000), the United Kingdom (Downie and Ford 1966, Lister et al. 1969, Molyneux 1979, Turner and Wadge 1979, Turner 1982, Downie 1984, Rushton 1985, Molyneux 1987, Trythall et al. 1987, Rushton and Molyneux 1989, Cooper and Molyneux 1990, Millward and Molyneux 1992, Cooper et al. 1995, Molyneux 1996, Molyneux and Leader 1997, and Molyneux 1999), Belgium (Martin et al. 1970, Martin 1974, 1977, Vanguestaine 1986, Servais 1991, Servais and Maletz 1992) and the Avalonian parts of Germany (Burmann 1970, 1976, Maletz and Servais 1993, Servais 1994)

The South American occurrences on eastern Gondwana include the localities investigated in Argentina by Rubinstein et al. 1999, Rubinstein and Toro 2001, and Rubinstein 2003)

\section{Conclusion}

The attempt of this paper is to provide a comprehensive review of the acritarch genus Coryphidium Vavrdová 1972. Based on a revision of published literature supplemented by studies of material from the British Isles, Belgium, the Czech Republic, Germany, Spain, Morocco, Algeria, Tunisia, Lybia and China, the original diagnoses, stratigraphical ranges and geographical distribution of all Coryphidium species are critically evaluated. Coryphidium is emended and the informal category of coryphid acritarchs is introduced to include all morphotypes with the characteristic vesicle shape of the two genera Coryphidium and Vavrdovella Loeblich and Tappan 1976. Nine of the previously described species clearly belong to Coryphydium, while two other species possibly belong to it. However, the attribution to Corphydium of the species C. sichuanense Wang and Chen 1987 is rejected 
here. Coryphidium seems to occur in all palaeoenvironments from nearshore to offshore settings and therefore does not seem to be palaeoecologically significant. Palaeogeographically, however, Coryphidium is of very great importance, as it is an indicator of the peri-Gondwanan acritarch 'palaeoprovince' during the Early/Middle Ordovician.

Coryphidium is also very useful biostratigraphically. The genus first appears in the uppermost Tremadocian Araneograptus murrayi graptolite Biozone and is common through the upper Lower Ordovician and the Middle Ordovician, while Upper Ordovician occurrences might be the result of reworking. The different morphotypes observed within the genus also appear to have a biostratigraphical importance, but this significance is limited because intraspecific variability is very high. 


\section{Acknowledgements}

This paper is respectfully dedicated to Prof. M. Tongiorgi who retired recently from Pisa University after many years of research on Ordovician acritarchs, including many records of Coryphidium. We are particularly greatful to numerous colleagues for discussion and valuable information helping to review the genus: R. Albani (Pisa), P. Breuer (Liège), R. Brocke (Frankfurt a.M.), G. Burmann (Berlin), O. Fatka (Prague), M. Ghavidel-syooki (Tehran), W. Mette (Innsbruck), C. Rubinstein (Mendoza), and M. Vanguestaine (Liège). We thank M. Vavrdová (Prague) for providing the Czech samples. The material from the Rügen boreholes has been made available by the Erdöl-Erdgas Gommern GmbH. We acknowledge the Office National de Recherches et d'Exploitations Pétrolières (ONAREP, Rabat) for providing the Moroccan samples. This paper is a result of a scientifical collaboration between the Chinese Academy of Sciences and the French CNRS (PICS programme). L.J. benefited from an invited professorship at the University of Lille 1 (USTL). Financial support is greatly acknowledged: CAS project KZCX2-SW130; NSFC project49972007; MSTC project G 20000077700. This is a contribution to IGCP 503 "Ordovician Palaeogeography and Palaeoclimate". 


\section{REFERENCES}

AHRENDT, H., RIBBERT, K.-L., VANGUESTAINE, M. and WEMMER, K. 2001. K-Ar and acritarch dationg of phyllite clasts from a resedimented MiddleDevonian conglomerate in the northwestern part of the Rhenish Slate Mountains. Z. dt. geol. Ges. 152(2-4) : 365-377.

ALBANI, R. 1989. Ordovician (Arenigian) acritarchs from the Solanas Sandstone Formation, Central Sardinia, Italy. Bolletino della Società Paleontologica Italiana, 28 (1) : 3-37.

ALBANI, R., LELKES-FELVARY, G. and TONGIORGI, M. 1985a. First record of Ordovician (Upper Arenigian acritarchs) beds in Bakony Mts., Hungary. N. Jb. Paläont. Abh., 45-65.

ALBANI, R., DI MILIA, A., MINZONI, N. and TONGIORGI, M. 1985b. Nuovi dati palinologici e consicerazioni geologiche sull'eta' delle arenarie di solanas (cambroordoviciano-sardegna centrale). Atti della società toscana di scienze naturali. Memorie, $91: 1-20$.

ARRIAGHA E CUNHA, T., and VANGUESTAINE, M. 1988. Acritrchs of the «Xistos com Phyllodocites » Formation, Barrancos Region, SE of Portugal. Comun. Serv. Geol. Portugal. $74: 69-77$.

BARCA, S., COCOZZA, T., DEL RIO, M. and PITTAU DEMELIA, P. 1981. Discovery of lower Ordovician acritarchs in the "Postgotlaniano» sequence of southwestern Sardinia (Italy) : age and tectonic implications. Boll. Soc. Geol. It. $100: 377-392$.

BAUDELOT, S. and FOURNIER-VINAS, C. 1984. Bassins paléozoïque cachés sous l'Aquitaine : étude micropaléontologique de carottes prélevées àl'occasion de forages pétroliers. Documents B. R. G . M. Orléans. 81 (7) : 1-11.

BROCKE, R., LI, J. and WANG, Y. 2000. Upper Arenigian to lower to lower Llanvirnian acritarch assemblages from South China: a preliminary evaluation. Review of Palaeobotany and Palynology, $113: 27-40$.

BROCKE, R., FATKA, O., MOLYNEUX, S. G. and SERVAIS, T. 1995. First appearance of selected Early Ordovician acritarch taxa from Peri-Gondwana. In : COOPER, J. D., DROSER, M. L. and FINNEY, S. C. (eds.), Ordovician Odyssey : Short papers for the seventh international symposium on the Ordovician System. The Pacific Section Society for Sedimentary Geology (SEPM), 77, Fullerton. 473-476.

BURMANN, G. 1970. Weitere organische Mikrofossilien aus dem unteren Ordovizium. Paläontologische Abhandlungen. Abteilung B. Paläobotanik, III(3/4) : 289-332.

BURMANN, G. 1976. Übersecht über das ordovizische Mikroplankton im Südteil der DDR(Vogtland, Wildenfelser Zwischengebirge). Jb. Geol. 7/8 : 47-62.

COCCHIO, A. M. 1981. Microflores des séeries du Paléozoique inférieur du Massif du Mouthoumet (Corières, Aude). Travaux du Laboratoire de Géologie Méditerranéenne Associée au C.N.R.S., Université Paul-Sabatier, Toulouse, 1-32.

COCCHIO, A. M. 1981. Données nouvelles sur les acritarches du Trémadoc et de l'Arenig dans le massif de Mouthoumet (Corbiès, France). Revue de micropaléontologie, 25 : 2638.

CONNERY, C. and HIGGS, K. T. 1999. Tremadoc-Arenig acritarchs from the Annascaul Formation, Dingle Peninsula, Co. Kerry, Ireland. Bollettino della Secietà Paleontologica Italiana, 38(2-3) : 133-153.

COOPER, A. H. and MOLYNEUX, S. G. 1990. The age and correlation of Skiddaw group ( early Ordovician ) sediments in the Cross Fell inlier (northern England). Geological Magazine, $127:$ 147-157.

COOPER, A. H., RUSHTON, A. W. A., MOLYNEUX, S. G., HUGHES, R. A., MOORE, R. M. and WEBB, B. C. 1995. The stratigraphy, correlation, provenance and 
palaeogeography of the Skiddaw Group ( Ordovician) in the English Lake District. Geological Magazine,132(2) : 185-211.

CRAMER, F. H. and DÍEZ, M. 1976. Seven new late Arenigian species of the acritarch Genus Coryphidium. Paläont. Z. 50 : 201-208.

CRAMER, F. H., ALLAM, B., KANES, W. H. and DÍEZ, M. 1974. Upper Arenigian to lower Llanvirnian acritarchs from the subsurface of the Tadla Basin in Morocco. Paleontographica B, $145:$ 182-190.

DEAN, W. T. and MARTIN, F. 1978. Lower Ordovician acritarchs and trilobites from Bell Island, Eastern Newfoundland. Bull. geol. Survey of Canada, 284 : 1-35.

DÍEZ, M. and CRAMER, F. H. 1977. Range chart of selected Lower Paleozoic acritarch taxa. II Index to parts I and II. Review of Palaeobotany and Palynology, 24 : 1-48.

DOWNIE, C. 1984. Acritarchs in British Stratigraphy. Geological Society London, special report $17: 1-26$.

DOWNIE, C. and FORD, T. D. 1966. Micofossils from the Manx Slate Series. Proc. Yorkshire Geol. Soc. 35 (3) : 307-322.

EISENACK, A., CRAMER, F. H. and DÍEZ, C. 1976. Katalog der fossilen Dinoflagellaten, Hystrichosphären und verwandten Mikrofossilien Band IV Acritarcha 2. Teil. Stuttgart, Schweitzerbart'sche Verlagsbuchhandlung, 1-863.

EISENACK, A., CRAMER, F. H. and DÍEZ, C. 1979. Katalog der fossilen Dinoflagellaten, Hystrichosphären und verwandten Mikrofossilien Band IV Acritarcha 3. Teil. Stuttgart, Schweitzerbart'sche Verlagsbuchhandlung, 1-533.

FANG XIAOSI, 1986. Ordovician Micropalaeoflora in Kunming Luquan Region, Yunnan Province and its stratigraphical significance. Professional Paper of Stratigraphy and Palaeontology. Geological Publishing House, 16 : 125-175.

FENSOME, R. A., WILLIANMS, G. L., BARSS, M. S., FREEMAN, J. M. and HILL, J. M. 1990. Acritarchs and fossil prasinophytes : an index to genera, species and intraspecific taxa. A. A. S. P. Contribution Series $25: 1-771$.

FENSOME, R. A., WILLIANMS, G. L., BARSS, M. S., FREEMAN, J. M. and HILL, J. M. 1991. Alphabetic listing of acritarch and fossil prasinophyte species. A. A. S. P. Contribution Series $26: 1-111$.

FOURNIER-VINAS, C. 1978. Acritarches Cambro-Ordovicien des Monts de Lacaune (Nord de la Montagne Noire, France). Palinologia, num. extror. 1 : 263-271.

FOURNIER-VINAS, C. 1985. Acritarches Ordoviciens des Zekkara (Maroc oriental). Geobios, 18. $6: 807-813$.

FOURNIER-VINAS, C. and DONNOT, M. 1977. Présence d'acritarches dans l'Ordovicien inférieur et le Cambrien des monts de l'est de Lacaune (Aveyron). Versant nord de la Montagne noire. Bull. du B. R. G. M., 2.1.2 : 121-129.

GAO LIANDA, 1991. Acritarch from the Lower Ordovician Hongshiyan Formation of Wuding, Yunnan. Geol. Review, 37(5) : 445-455.

GHAVIDEL-SYOOKI, M. 1990. The encountered acritarchs and chitinozoans from Mila, Ilebed and Zard Kuh Formation in Tang-e-Ilebek at Zard Kuh and their correlation with the Palaeozoic sequence at Chal-i-Sheh area. Proceeding of Symposium on Diapirism with special reference to Iran, $\mathrm{pp}$. (in Percian with English abstract).

GHAVIDEL-SYOOKI, M. 1994. Biostratigraphy and Paleo-biogeography of some Paleozoic rocks at Zagros and Alborz mountains. In : HUSHMANDZADIH, A. (ed.), Geology of Iran. 1-168.

GHAVIDEL-SYOOKI, M. 1995. Palynostratigraphy and palaeogeography of a Paleozoic sequence in the Hassanakdar area, Central Alborz Range, northern Iran. Review of Palaeobotany and Palynology, 86 : 91-109. 
GHAVIDEL-SYOOKI, M. 2001. Palynostratigraphy and palaeogeography of the Lower Paleozoic sequence in the northeastern Alborz Range (Kopet-Dach Region) of Iran. In : GOODMAN, D. K. and CLARKE, R. T.(eds.), Proceedings of the IX International Palynological Congress, Houston, Texas, U. S. A., 1996 ; American Association of Stratigraphic Palynologists Foundation, 17-35.

HERBOSCH, A., VANGUESTAINE, M., DEGARDIN, J. M., DEJONGHE, L. and SERVAIS, T. 1991. Etude lithostratigraphique, biostratigraphique et sédimentologique du sondage de Lessines (bord méridional du Massif du Brabant, Belgique). Ann. Soc. Géol. Belgique, 114 : 195-212.

KALVACHEVA, R. 1979. Palynological evidence (acritarcha) for the age of the lower Palaeozoic rocks in the Vakarel Hill, Bulgaria. C. R. Acad. Bulgare des Sciences, 32(10) : 1397-1400.

KALVACHEVA, R. 1980. Upper Arenigian to lower Llanvirnian acritarchs from West Sredna Gora Mountain, Bulgaria. Abstracts $5^{\text {th }}$ International Palynological Congress, Cambridge, 196.

KALVACHEVA, R. 1982a. Palynological evidence of the earl-Ordovician (Arenigian) age of Ophiolites in the Botevgrad district (West Balkan Mountain) Bulgaria. C. R. Acad. Bulgare des Sciences, 35 : 1101-1104.

KALVACHEVA, R. 1982b. Palynology and Stratigraphy of the Diabase-Phyllitoid Complex in the West Balkan Mountains. Rev. Of the Bulgarian Geological Society, 43 : 8-24.

KALVACHEVA, R. 1986. Acritarch Stratigraphy of the Ordovician system in Bulgaria. IGCP profect $n^{\circ} 5$ : Correlation of Prevariscan and Variscan Events in the Alpine Mediterranean Mountain Belts. Final Meeting, Sardinia, abstracts, p. 38-43.

KLEBS, G. 1972. Über flagellaten- und algen-ähnliche Peridineen. Naturhistorisch Medizinischer Verein, Heidelberg, Verhandlungen,Neue Folge, 11 : 369-451.

LI JUN, 1987. Ordovician acritarchs from the Meitan Formation of Guizhou province, SouthWest China. Palaeontology, 30 :613-634.

LI JUN, 1989. Early Ordovician Mediterranean Province acritarchs from Upper Yangtze Region, China. In : SUN SHU(ed.), Developments in Geoscience. Beijing : Science Press : 231-234.

LI JUN, 1990. Ordovician acritarchs from the Jiuxi Formation of Jishou, Hunan. Acta Micropalaeontologica Sinica, 7 : 141-160.

LI JUN, 1991. The Early Ordovician acritarchs from Southwest China. Unpublished Ph. D. Thesis, Nanjing Institute of Geology and Palaeontology, Academia Sinica, Nanjing (in Chinese with English summary).

LI JUN, 1995. Acritarchs. In : CHEN XU, RONG JIA-YU, WANG XIAO-FENG, WANG ZHI-HAO, ZHANG YONG-DONG, ZHAN REN-BIN(eds.), Correlation of the Ordovician Rocks of China. Charts and Explanatory Notes. International Union of Geological Sciences Publication, Trondheim, $31: 20$.

LI JUN and YUAN XUNLAI, 1995. Early Ordovician Armorican quartzite facies from eastern Yunnan, China, Journal of Stratigraphy, 19: 58-61 ( in Chinese with English abstract).

LI JUN and YUAN XUNLAI, 1997. Arenigian acritarchs from the Upper Yangtze Region, Southern China. Journal of Stratigraphy, 21: 281-288 ( in Chinese with English translation).

LI JUN and YUAN XUNLAI, 1998. Arenigian acritarchs from the Chaochiapa Formation of Ningqiang County, Shaanxi Province. Acta Micropalaeontologica Sinica, 15 :272-285 ( in Chinese with English abstract). 
LI JUN, WANG YI and BROCKE, R., 2000. Ordovician acritarchs from the Shigtzupu Formation of Tongzi, Guizhou . Acta Micropalaeontologica Sinica, $17: 30-38$ ( in Chinese with English abstract).

LI JUN, WANG YI, SERVAIS, T. and BROCKE, R. 2002. Ordovician acritarchs from Meitan Formation of Huanghuachong, Guizhou, South China. Acta Palaeontologica Sinica, 41(1) :96-104 ( in Chinese with English abstract).

LISTER, T. R., BURGESS, I. C. and WADGE, A. J. 1969. Micorfossils from the cleaved skiddaw slates of Murton Pike and Brownber (Cross Fell Inlier). Geological Magazine, $106: 97-99$.

LOEBLICH, A. R. and TAPPAN, H. 1976. Some new and revised organic-walled phytoplankton microfossil genera. Journal of Paleontology, 52 : 1233-1287.

MARHOUMI, M. R., RAUSCHER, R. and VANGUESTAINE, M. 1982. Les microfossiles (chitinozoaires et acritarches) des schistes du Tazekka au Maroc oriental. Sci. Géol. Bull., 35 :137-145.

MARTIN, F., 1974. Ordovicien supérieur et Silurien inférieur à Deerlijk (Belgique). Mém. Inst. r. Sc. Nat. belg., $174: 1-71$.

MARTIN, F., 1977. Acritarches du Cambro-Ordovicien du Massif du Brabant, Belgique. Bull. Inst. r. Sci. Nat. belg., 51 : 1-33.

MARTIN, F., 1982. Some aspects of late Cambrian and early Ordovician Acritarchs. In : BASSETT, M. G. and DEAN, W. T. (eds.), The Cambrian-Ordovician boundary : sections, fossil distributions, and correlations. National Museum of Wales, Geological Series : 29-40.

MARTIN, F. 1993. Acritarchs : a review. Biol. Rev. 68 : 475-538.

MARTIN, F. 1996. Recognition of the acritarch-based «trifidum flora (Ordovician) in the absence of the eponymous species. Bulletin de L'institut royal des Sciences naturelles de Belgique, 66 : 5-13.

MARTIN, F. and RICKARDS, B. 1979. Acritarches, chitinozoaires et graptolithes ordoviciens et siluriens de la vallande de la Sennette (Massif du Brabant, Belgique). Ann. Soc. Géol. Belgique, 102 : 189-197.

MARTIN, F., MICHOT, J. and VANGUESTAINE, M. 1970. Le flysch caradocien d'Ombret. Ann. Soc. Géol. Belgique, 93 : 337-362.

MAZIANE-SERRAJ, BRÜCK, P. M., HIGGS, K. T. and VANGUESTAINE, M. 2000. Ordovician and Silurian acritarch assemblages from the west Leinster and Slievenamon areas of southeast Ireland. Review of Palaeobotany and Palynology, 113 : 57-71.

MACCAFFREY, W. D., BARRON, H. F., MOLYNEUX, S. G. and KNELLER, B. C. 1992. Recycled acritarchs as provenance indicators: implications for Caledonian terrane reconstruction. Geological Magazin, 129(4) : 457-464.

METTE, W., 1989. Acritarchs from Lower Paleozoic rocks of the western Sierra Morena, SW-Spain and biostratigraphic results. Geologica et Palaentologica, 23 : 1-19.

MILLWARD, D and MOLYNEUX, S. G., 1992. Field and biostratigraphic evidence for an unconformity at the base of the Eycott Volcanic Group in the English Lake District. Geol. Mag., 129 : 77-92.

MOLYNEUX, S. G. 1979. New evidence for the age of the Manx Group, Isle of Man. In : HARRIS, A. L., HOLLAND, C. H. and LEAKE, B. E. (eds.). The Caledonides of the British Isles-reviewed. Geological Society, London, Special Publication, $8: 415-421$.

MOLYNEUX, S. G. 1987. Appendix. Acritarchs and Chitinozoa from the Arenig Series of south-west Wales. Bull. Br. Mus. Nat. Hist. (Geol.), 41 : 309-364.

MOLYNEUX, S. G. 1990. Advances and problems in Ordovician palynology of England and Wales. Journal of the Geological Society, London, 147 : 615-618. 
MOLYNEUX, S. G. 1996. The stratigraphical significance of Coryphidium morphotypes in the Lower Ordovician Skiddaw Group of the English lake District. Acta Universitatis Carolinae Geologica 40(1996) : 545-548. Editum 17(4), 1997.

MOLYNEUX, S. G. 1998. An upper Dalradian microfossil reassessed. Journal of the Geological Society, London, 155 : 741-743.

MOLYNEUX, S. G. 1999. An reassessment of Manx Group acritarchs, Isle of Man. In : WOODCOCK, N. H., QUIRK, D. G., FITCHES, W. R. and BARNES, R. P. (eds.), In Sight of the Suture : the Palaeozoic geology of the Esle of Man in its Iatetus Ocean context. Geological Societ, London, Special Publications, 160 : 23-32.

MOLYNEUX, S. G. and LEADER, R. U. 1997. Morphological variation in Coryphidium from the Arenigian Series (Lower Ordovician) of northwestern England. Review of Palaeobotany and Palynology, $98: 81-94$.

QUINTAVAllE, M., TONGIORGI, M. and GAETANI, M. 2000. Lower to Middle Ordovician acritarchs and chitinozoans from Northern Karakorum mountains, Pakistan. Rivista Italiana di Paleontologia e Stratigarfia , 106 (1) : 3-18.

RAUSCHER, R. 1974. Recherches micropaléontologiques et stratigraphiques dans l'Ordovicien et le Silurien de la France. Méloires de l'Université Louis Pasteur (Strasbourg), Sciences géologiques, 38 : 1-224.

REITZ, E. 1994. Unterordovizische Acritarchen aus der Magdalensberg-Gruppe in Ostkärnten und aus der Salzburger Rrauwackenzone (Österreich), Jahrbuch der geologischen Bundesanstalt, 137(4) : 661-668.

REITZ, E. and HÖLL, R., 1991. Biostratigraphischer Nachweis von Arenig in der Nördlichen Grauwackenzone (Ostalpen). Jb. Geol. B.-A. , 134 : 329-344.

REITZ, E. and HÖLL, R., 1992. Palynological evidence for Lower Ordovician rocks (Tremadoc and Arenig) in the Northern Greywacke Zone (EasternAlps). Terra Nova, 4 : 198-207.

RUBINSTEIN, C. V., TORO, B. A. and WAISFELD, B. G. 1999. Acritarch biostratigraphy of the upper Trmadoc-Arenig of the Eastern Cordillera, north western Argentina: relationships with graptolite and trilobite faunas. Bolletino della Società Paleontologica Italiana. 38 (2-3) : 267-286.

RUSHTON, A. W. A. and MOLYNEUX, S. G. 1989. The biostratigraphic age of the Ordovician Skiddaw Group in the Black Combe Inlier, English Lake District. Proceedings of the Yorkshire geological Society, 47 (3) : 267-276.

SERVAIS, T. 1991. Contribution to the stratigraphy of the Ordovician Rigenée formation (Rbabant Massif, Belgium) with preliminary studies on Acritarchs. Annales de la Société Géologique de Belgique, 114 : 233-245.

SERVAIS, T. 1995. Paleobiogeography of Ordovician acritarchs : some general considerations. In : COOPER, J. D., DROSER, M. L. and FINNEY, S. C. (eds.), Ordovician Odyssey: Short papers for the seventh international symposium on the Ordovician System. The Pacific Section Society for Sedimentary Geology(SEPM), 77, Fullerton.

457-460.

SERVAIS, T. and FATKA, O. 1997. Recognition of the Trans-European Suture Zone (TESZ) by the palaeobiogeographical distribution pattern of early to middle Ordovician acritarchs. Geological Magazine, 134 (5) : 617-625.

SERVAIS, T. and METTE, W. 2000. The messaoudensis-trifidum acritarch assemblage (Ordovician: late Tremadoc-early Arenig) of the Barriga Shale Formation, Sierra Morena (SW-Spain). Review of Palaeobotany and Palynology, 113 : 145-163.

SMITH, D. G. 1981. Progress in Irish Lower Palaeozoic Palynology. Rev. Palaeobot. Palynol. $34: 137-148$. 
TODD, S. P., CONNERY, C., HIGGS, K. T. and MURPHY F. C. 2000. An Early Ordovician age for the Annascaul Formaton of the SE Dingle Peninsula, SW Ireland. Journal of Geological Society, London, 157 : 823-833.

TONGIORGI, M., ALBANI, R. and DI MILIA, A. 1984. The Solanas Sandstones of Central Sardinia: new paleontological data (Acritarchs ) and an attempt of geological interpretation (a « post-sardinian » mosasse ?). Bull. Soc. géol. France, $26: 665-680$.

TONGIORGI, M., YIN LEI-MING and DI MILIA, A. 1995. Arenigian acritarchs from the Daping section (Yangtze Gorges area, Hubei Province, Southern China) and their palaeogeographic significance. Review of Palaeobotany and Palynology, 86 : 13-48.

TONGIORGI, M., DI MILIA, A. LE FORT , P. and GAETANI, M. 1994. Palynological dating (Arenig) of the sedimentary sequence overlying the Ishkarwaz Granite (upper Yanjhun valley, Chitral, Pakistan). Terra Nova, 6 : 595-607.

TONGIORGI, M., YIN LEI-MING,DI MILIA, A. and RIBECAI C. 1998. Changing paleogeographical affinities of the Arenigian acritarch assemblages throughout the Dawan Formation (Arenig, Yichang, South China). Palynology, 22 : 181-196.

TRYTHALL, R. J. B., ECCLES, C., MOLYNEUX, S. G. and TAYLOR, W. E. G. 1987. Age and control of ironstone deposition ( Ordovician) North Wales. Geological Journal, 22 : 31-43.

TURNER, R. E. 1982. Reworked acritarchs from the type section of the Ordovician Caradoc Series, Shropshire. Palaeontology, 25 : 119-143.

TURNER, R. E. and WADGE, A. J. 1979. Acritarch dating of Arenig Volcanism in the Lake district. Proc. of the Yourkshire Geol. Soc., 42 : 405-414.

VANGUESTAINE, M. 1986. Progrès récents de la stratigraphie par Acritarches du CambroOrdovicien d'Irlande, d'Angleterre, du Pays de Galles et de Terre-Neuve orientale. Ann. Soc. géol. Nord (France), $105: 65-76$.

VAVRDOVÁ , M. 1972. Acritarchs from Klabava shales. Vestnik Ustredniho ustavu geologickeho, 47 : 79-86.

VAVRDOVÁ , M. 1973. New acritarchs from Bohemian Arenig(Ordovician). Vestnik Ustredniho ustavu geologickeho, 48: 285-289.

VAVRDOVÁ, M. 1974. Geographical differentiation of Ordovician acritarch assamblages in Europe. Rev. Palaeobot. Palynol., 18 : 171-176.

VAVRDOVÁ, M. 1976. Excystment mechanism of Early Paleozoic acritarchs. Casopsis pro mineralogii a geologii, $21: 55-64$.

VAVRDOVÁ , M. 1977. Acritarchs from the Sarka Formation (Llanvirnian). Vestnik Ustredniho ustavu geologickeho, 52: 109-118.

VAVRDOVÁ, M. 1982a. Phytoplankton communities of Cambrian and Ordovician age of Central Bohemia. Vestnik Ustredniho ustavu geologickeho, 57 : 145-155.

VAVRDOVÁ, M. 1982b. Recycled acritarchs in the uppermost Ordovician of Bohemia. Casopsis pro Mineralogii a geologii , 27 : 337-345.

VAVRDOVÁ, M. 1986. New genera of acritarchs from the Bohemia Ordovician. Casopsis pro Mineralogii a geologii , 31: 349-360.

VAVRDOVÁ , M. 1988. Further acritarchs and terrestrial plant remains from the Late Ordovician at Hlasna Treban, Czechoslovakia. Casopsis pro Mineralogii a geologii , 33: 349-360.

VAVRDOVÁ, M. 1989. New acritarchs and miospores from the Late Ordovician of Hlasna Treban, Czechoslovakia. Casopsis pro Mineralogii a geologii , 34 (4): 403-420.

VAVRDOVÁ , M. 1990a. Coenobial acritarchs and other palynomorphs from the Arenig/Llanvirn boundary, Prgue basin. Vestnik Ustredniho ustavu geologickeho, 65: 237-242. 
VAVRDOVÁ, M. 1990b. Early Ordovician acritarchs from the locality Myto near Rckycany (late Arenig, Czechoslovakia). Casopsis pro Mineralogii a geologii , 35: 239-250.

VAVRDOVÁ, M. 1997. Early Ordovician acritarch probincialism in acritarch distribution. Review of Palaeobotany and Palynology, $98: 33-40$.

VECOLI, M. 1999. Cambro-Ordovician palynostratigraphy ( acritarchs and prasinophytes) of the Hassi-R'Mel area and northern Rhadames Basin, North Africa. Palaeontographia Italica, $86: 1-112$.

VECOLI, M., TONGIORGI, M. and ABDESSELAM-ROUGHI, F.-F. 1999. Palynostratigraphy of Upper-Cambrian-upper Ordovician intracratonic clastic seauences, North Africa. Bolletino della Società Paleontologica Italiana. 38 (2-3) : 331341.

WANG FUXING and CHEN QIAO, 1987. Spinifeuous acritarchs from the lowerest Cambrian, Emei, Sichuan, southwestern China. Rev. Palaeobot. Palynol. 52 : 161-177.

XING YUSHENG, 1980. Microplants and chitinozoans from the lower Ordovician Dachengsi Formation of Emeishan, Sichuan. Abstracts $5^{\text {th }}$ International Palynological Congress, Cambridge, 438.

XU WAN-HONG 1995. Acritarchs from the Etagraptus approximatus Biozone of Arenigian in the Sandu area of Guizhou Province. Acta Micropalaeontologica Sinica, 16, 61-75.

XU WAN-HONG, ZHANG ZHONG-YING, HUANG JIE-WEN and ZHANG HAI-FENG, 1995. Discovery of Arenigian acritarchs from Sandu, Guizhou, and its geological significance. Acta Micropalaeontologica Sinica, 12 (3) : 285-292 (in Chinese with English abstract).

YIN LEI-MING, 1995. Early Ordovician acritarchs from Hunjiang region, Jilin, and Yichang region, Hubei, China. Palaeontologia Sinica, New Sir. A 185, 1-170 ( in Chinese with English translation ). 


\section{Plate 1.}

Scale bar $=10 \mu \mathrm{m}$.

Fig. 1. Coryphidium cf. barakum. Borehole BJ 109, Morocco -511 m, slide 20541, EF: J34/3. Fig. 2. Coryphidium cf. almohadillum. Borehole BJ 109, Morocco -511 m, slide 20541, EF: N31.

Fig. 3. Coryphidium cf. bohemicum Borehole BJ 109, Morocco -511 m, slide 20541, EF: M32/4.

Fig. 4. Coryphidium cf. bohemicum. Borehole BJ 109, Morocco -511 m, slide 20541, EF: M33.

Fig. 5. Coryphidium cf. elegans. Borehole BJ 109, Morocco -511 m, slide 20541, EF: F34/4.

Fig. 6. Coryphidium cf. bohemicum. Borehole BJ 109, Morocco -511 m, slide 20541, EF: $\mathrm{J} 37 / 1$.

Fig. 7. Coryphidium cf. barakum. Borehole BJ 109, Morocco -511 m, slide 20541, EF: P34.

Fig. 8. Coryphidium cf. bohemicum. Borehole BJ 109, Morocco -511 m, slide 20541, EF: $\mathrm{T} 31 / 4$.

Fig. 9. Coryphidium cf. bohemicum. Borehole BJ 109, Morocco -511 m, slide 20541, EF: O31.

Fig. 10. Coryphidium cf. miladae. Borehole BJ 109, Morocco -511 m, slide 20541, EF: P34/2. Fig. 11. Coryphidium cf. bohemicum. Borehole BJ 109, Morocco -511 m, slide 20541, EF: M45.

Fig. 12. Coryphidium cf. miladae. Borehole BJ 109, Morocco -511 m, slide 20541, EF: O44/1.

\section{Planche 1.}

Barre d'échelle $=10 \mu \mathrm{m}$.

Fig. 1. Coryphidium cf. barakum. Sondage BJ 109, Maroc -511 m, lame 20541, EF : J34/3.

Fig. 2. Coryphidium cf. almohadillum. Sondage BJ 109, Maroc -511 m, lame 20541, EF : N31.

Fig. 3. Coryphidium cf. bohemicum Sondage BJ 109, Maroc -511 m, lame 20541, EF : M32/4.

Fig. 4. Coryphidium cf. bohemicum. Sondage BJ 109, Maroc -511 m, lame 20541, EF : M33.

Fig. 5. Coryphidium cf. elegans. Sondage BJ 109, Maroc -511 m, lame 20541, EF : F34/4.

Fig. 6. Coryphidium cf. bohemicum. Sondage BJ 109, Maroc -511 m, lame 20541, EF : $\mathrm{J} 37 / 1$.

Fig. 7. Coryphidium cf. barakum. Sondage BJ 109, Maroc -511 m, lame 20541, EF : P34.

Fig. 8. Coryphidium cf. bohemicum. Sondage BJ 109, Maroc -511 m, lame 20541, EF : $\mathrm{T} 31 / 4$.

Fig. 9. Coryphidium cf. bohemicum. Sondage BJ 109, Maroc-511 m, lame 20541, EF : O31.

Fig. 10. Coryphidium cf. miladae. Sondage BJ 109, Maroc -511 m, lame 20541, EF : P34/2.

Fig. 11. Coryphidium cf. bohemicum. Sondage BJ 109, Maroc -511 m, lame 20541, EF : M45.

Fig. 12. Coryphidium cf. miladae. Sondage BJ 109, Maroc -511 m, lame 20541, EF : O44/1. 


\section{Plate 2.}

Scale bar $=10 \mu \mathrm{m}$.

Fig. 1. Coryphidium elegans. Klabava Formation, Krusna Hora, "Gabriela mine", Czech Republic, slide No. 22497, EF: E42/3.

Fig. 2. Coryphidium cf. bohemicum. A. suecicus graptolite zone, Meitan Formation (Honghuayan section), Guizhou Province, southeastern China. Sample No. AF1048, slide 1, EF: V29.

Fig. 3. Coryphidium bohemicum. Borehole ST1, Tunisia. Sample 1554, slide 10, EF: P39/2.

Fig. 4. Teratological specimen of ?Coryphidium sp., devoid of processes. Borehole BJ 109, Morocco -511m EF: Q36.

Fig. 5. Coryphidium cf. elegans. U. austrodentatus graptolite zone, Meitan Formation (Honghuayan section), Guizhou Province, southeastern China. Sample No. AF1093, slide 1, EF: L41/1.

Fig. 6. Coryphidium cf. elegans. U. austrodentatus graptolite zone, Meitan Formation (Honghuayan section), Guizhou Province, southeastern China. Sample No. AF1093, slide 2, EF: T39/1.

Fig. 7. Coryphidium cf. elegans. U. austrodentatus graptolite zone, Meitan Formation (Honghuayan section), Guizhou Province, southeastern China. Sample No. AF1093, slide 2, EF: V34/3.

\section{Planche 2.}

Barre d'échelle $=10 \mu \mathrm{m}$.

Fig. 1. Coryphidium elegans. Formation de Klabava, Krusna Hora, " Gabriela Mine », République Tchèque, lame no 22497, EF : E42/3.

Fig. 2. Coryphidium cf. bohemicum. Zone à graptolites A. suecicus, Formation de Meitan (section de Honghuayan), Province de Guizhou, sud-est de la Chine. Échantillon no AF1048, lame 1, EF : V29.

Fig. 3. Coryphidium bohemicum. Sondage ST1, Tunisie. Échantillon 1554, lame 10, EF : $\mathrm{P} 39 / 2$.

Fig. 4. Spécimen tératologique de ? Coryphidium sp., sans processus. Sondage BJ 109, Maroc $-511 \mathrm{~m}, \mathrm{EF}: \mathrm{Q} 36$.

Fig. 5. Coryphidium cf. elegans. Zone à graptolites $U$. austrodentatus, Formation de Meitan (section de Honghuayan), Province de Guizhou, sud-est de la Chine. Èchantillon no AF1093, lame 1, EF : L41/1.

Fig. 6. Coryphidium cf. elegans. Zone à graptolites U. austrodentatus, Formation de Meitan (section de Honghuayan), Province de Guizhou, sud-est de la Chine. Échantillon no AF1093, lame 2, EF : T39/1.

Fig. 7. Coryphidium cf. elegans. Zone à graptolites U. austrodentatus, Formation de Meitan (section de Honghuayan), Province de Guizhou, sud-est de la Chine. Échantillon no AF1093, lame 2, EF : V34/3. 
Figure 1. Palaeogeographical distribution of the genus Coryphidium in the Early-Middle Ordovician. Palaeogeographical reconstruction adopted from Li and Servais (2002), modified after Li and Powell (2001). Legend of selected locations (for explanations and complete list of locations see Text): 1. Yangtze Platform, South China; 2. Karakorum and Chitral, Pakistan; 3. Alborz Mts, Iran; 4. Taurus Mts, Turkey; 5. West Balkan Mts, Bulgaria; 6. Bakony Mts, Hungary; 7. Sierra Morena, Spain, and Barrancos, Portugal; 8. Sahara subsurface, Lybia, Tunisia, Algeria; 9. Tadla Basin, Morocco; 10. Bohemia, Czech Republic; 11. Rügen Island, Germany; 12. English Lake District, Isle of Man and Wales, United Kingdom; 13. Random and Bell Islands, Newfoundland; 14. Eastern Cordillera, Argentina.

Figure 1. Distribution paléogéographique du genre Coryphidium dans l'Ordovicien inférieur et moyen. Réconstitution paléogéographique d'après Li et Servais (2002), modifiée d'après Li et Powell (2001). Légende des localités (pour plus d'explications et la liste complète des localités, voir le Texte) : 1. Plateforme Yangtze, sud de la Chine ; 2. Karakorum et Chitral, Pakistan ; 3. Alborz Mts., Iran ; 4. Taurus Mts, Turquie ; 5. West Balkan Mts, Bulgarie ; 6. Bakony Mts, Hongrie ; 7. Sierra Morena, Espagne, et Barrancos, Portugal ; 8. Sahara, Libya, Tunisie, Algérie ; 9. Bassin de Tadla, Maroc ; 10. Bohème, République tchèque ; 11. Île de Rügen, Allemagne ; 12. English Lake District, Angleterre ; Isle of Man et Pays de Galles, Royaume Uni ; 13. Îles de Random et Bell, Terre-Neuve ; 14. Cordillère Orientale, Argentine. 

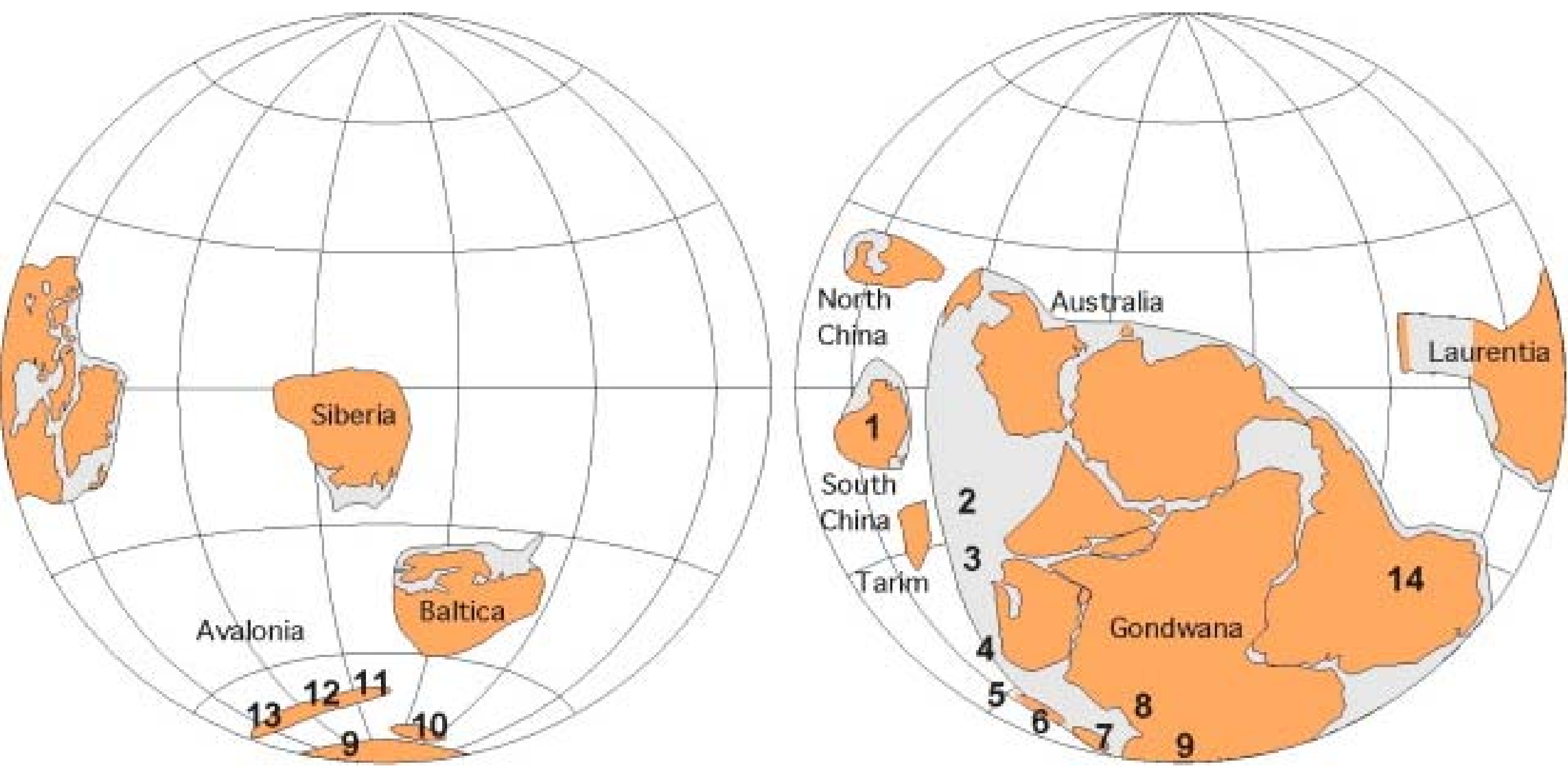

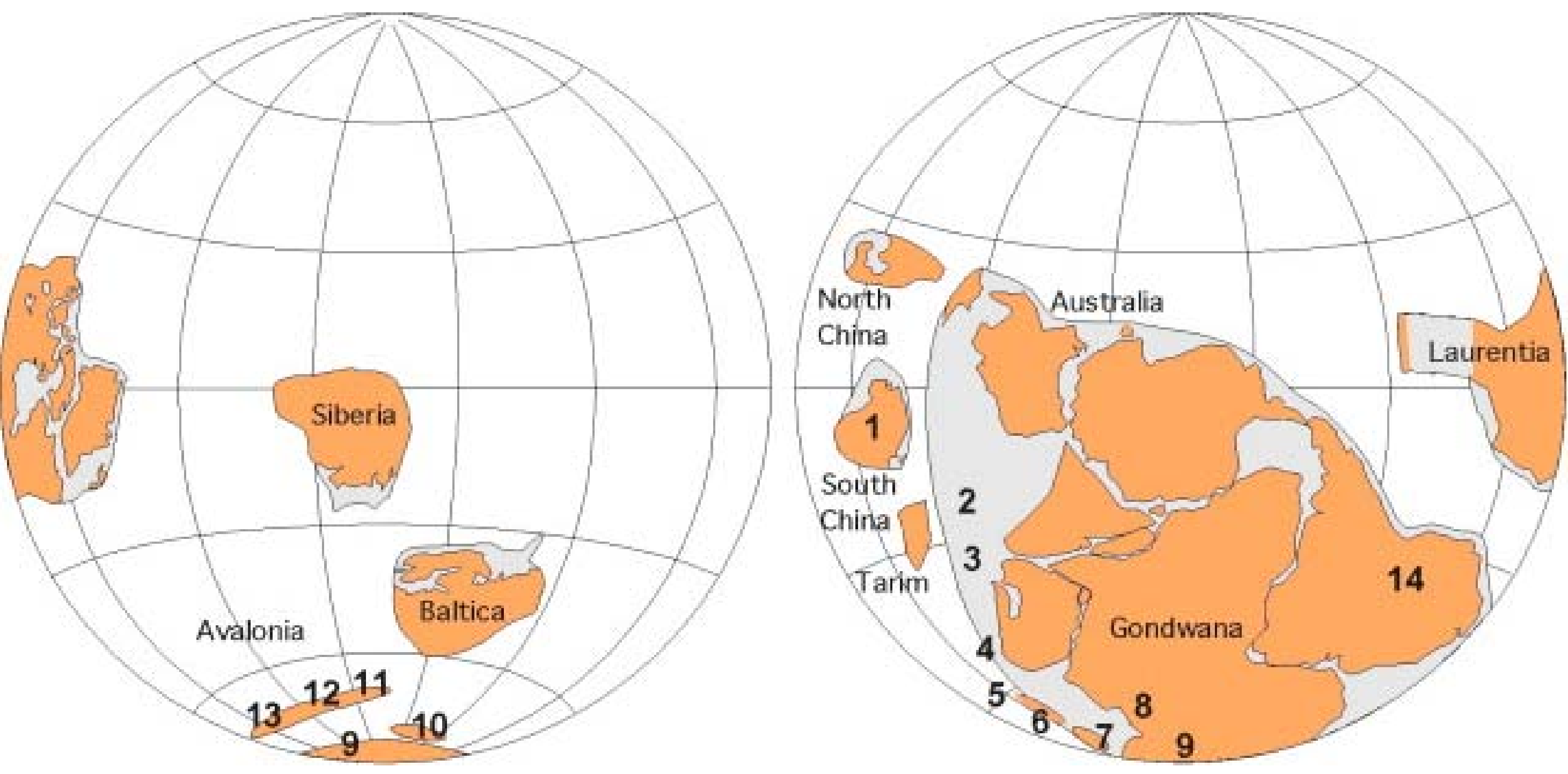

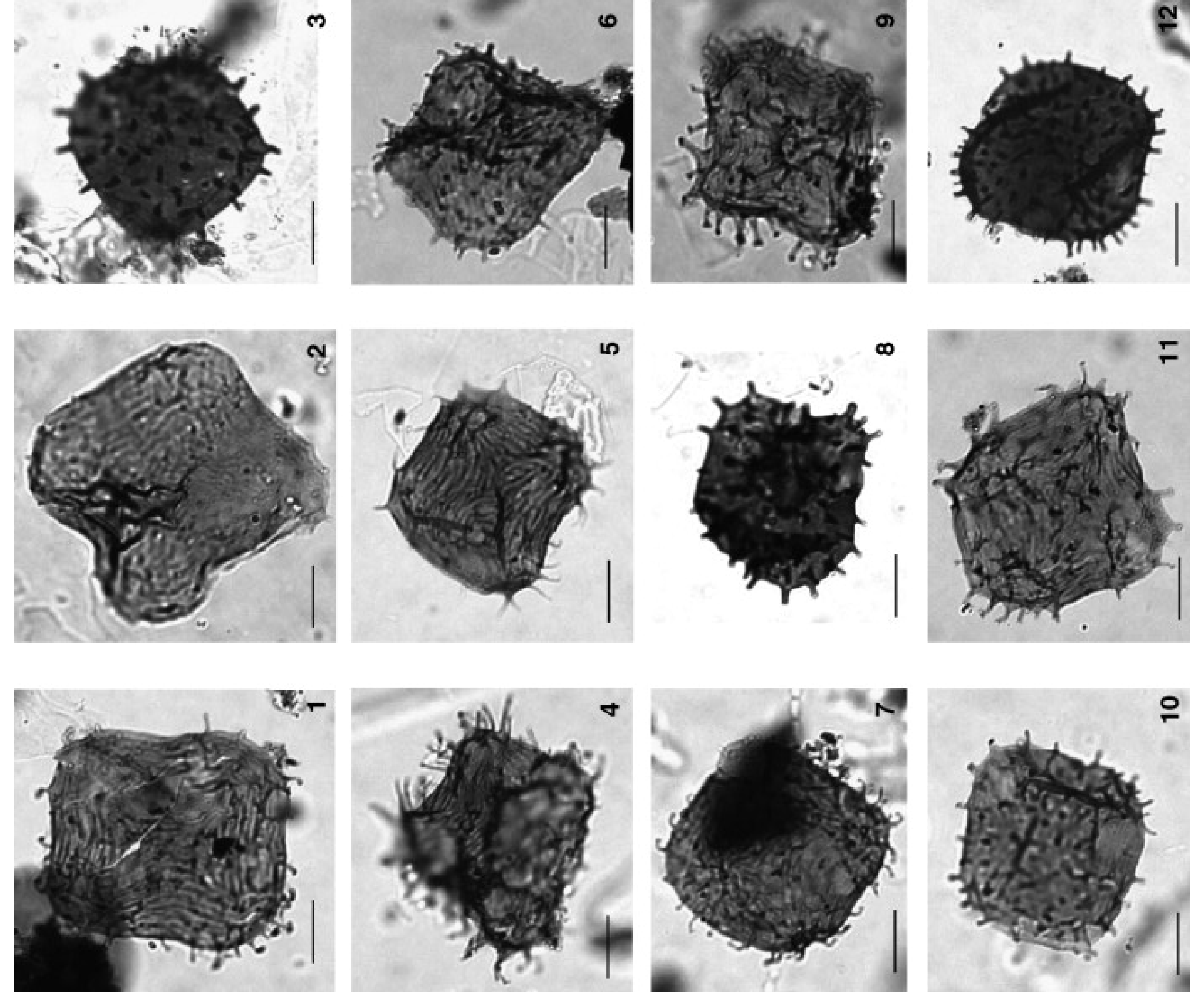
